\title{
Contribution from the ten major emission sectors in Europe and Denmark to the health-cost externalities of air pollution using the EVA model system - an integrated modelling approach
}

\author{
J. Brandt ${ }^{1}$, J. D. Silver ${ }^{1}$, J. H. Christensen ${ }^{1}$, M. S. Andersen ${ }^{1}$, J. H. Bønløkke ${ }^{2}$, T. Sigsgaard ${ }^{2}$, C. Geels ${ }^{1}$, A. Gross ${ }^{1}$, \\ A. B. Hansen ${ }^{1}$, K. M. Hansen ${ }^{1}$, G. B. Hedegaard ${ }^{1, *}$, E. Kaas ${ }^{3}$, and L. M. Frohn ${ }^{4}$ \\ ${ }^{1}$ Aarhus University, Department of Environmental Science, Frederiksborgvej 399, 4000 Roskilde, Denmark \\ ${ }^{2}$ Aarhus University, Section of Environment, Occupation, and Health, Institute of Public Health, Bartholins Allé 2, Building \\ 1260, 8000 Aarhus C, Denmark \\ ${ }^{3}$ University of Copenhagen, Planet and Geophysics, Niels Bohr Institute, Juliane Maries Vej 30, 2100 Copenhagen, Denmark, \\ Denmark \\ ${ }^{4}$ Aarhus University, AU Knowledge, Tuborgvej 164, 2400 København NV, Denmark \\ *now at: Centre for Environmental and Climate Research, Lund University, Sölvegatan 37, 22362 Lund, Sweden
}

Correspondence to: J. Brandt (jbr@dmu.dk)

Received: 7 January 2013 - Published in Atmos. Chem. Phys. Discuss.: 6 March 2013

Revised: 2 July 2013 - Accepted: 3 July 2013 - Published: 12 August 2013

\begin{abstract}
We have developed an integrated model system, EVA (Economic Valuation of Air pollution), based on the impact-pathway chain, to assess the health-related economic externalities of air pollution resulting from specific emission sources or sectors, which can be used to support policymaking with respect to emission control. Central for the system is a newly developed tagging method capable of calculating the contribution from a specific emission source or sector to the overall air pollution levels, taking into account the non-linear atmospheric chemistry. The main objective of this work is to identify the anthropogenic emission sources in $\mathrm{Eu}-$ rope and Denmark that contribute the most to human health impacts. In this study, we applied the EVA system to Europe and Denmark, with a detailed analysis of health-related external costs from the ten major emission sectors and their relative contributions. The paper contains a thorough description of the EVA system, the main results from the assessment of the main contributors and a discussion of the most important atmospheric chemical reactions relevant for interpreting the results. The main conclusion from the analysis is that the major contributors to health-related external costs are major power production, agriculture, road traffic, and nonindustrial domestic combustion, including wood combustion. We conclude that when regulating the emissions of ammonia
\end{abstract}

from the agricultural sector, both the impacts on nature and on human health should be taken into account. This study confirms that air pollution constitutes a serious problem for human health and that the related external costs are considerable. The results in this work emphasize the importance of defining the right questions in the decision-making process. The results from assessing the impacts from each emission sector depend clearly on the assumption that the other emission sectors are not changed, especially emissions changing concentrations of atmospheric $\mathrm{OH}$ and therefore lifetimes of other chemical species.

\section{Introduction}

To determine an optimal regulatory strategy for reducing the negative effects of air pollution on human health, it is valuable to calculate the contribution from various anthropogenic emission sources to the air pollution concentration levels, using a chemistry transport model (CTM), and the resulting health-related external costs (i.e. the indirect cost associated with the activities resulting in emissions). This can be done by assessing the impacts of a hypothetical change in 
emissions, which may be useful for policy planning and regulatory measures.

Within the recent decades, many of the emission sources/sectors have received considerable attention and actions have been taken to regulate emissions where feasible. One could claim that the most visible sectors have been the primary targets of regulation; for example, catalysts and filters have been installed in power plants and vehicles to reduce the amount of pollution emitted (e.g. $\mathrm{SO}_{\mathrm{x}}, \mathrm{PM}$, and $\mathrm{NO}_{\mathrm{x}}$ ). Furthermore, actions have been taken to remove harmful compounds (such as lead, benzene, and sulfur) from gasoline and diesel fuels. All of these actions have had a positive, measurable, and significant impact on air pollution levels. However, there are many other sources to air pollution located relatively close to major population centres. When quantifying emissions, more than ten major emission sectors (defined by SNAP categories) are defined, of which the major power plants and road traffic constitute two. Emission sources do not have to be close to where people dwell in order to have a significant impact on health. Air pollution can be transported in the atmosphere over thousands of kilometres, and many of the harmful compounds (e.g. the secondary inorganic particles) are produced by chemical reactions along the way, hours or days after their primary compounds are emitted. Thus it is not necessarily the most obvious, visible, and closest emission sources that cause the greatest impacts on human health or the environment. Emission sources at great distance can have as significant and equally important impacts as nearby sources.

The main goal of this work is to examine the contribution from ten major SNAP emission sectors in Europe and Denmark and quantify their relative importance in terms of their impacts on human health and related external costs, both on the European scale and for Denmark, as examples of support for both international and national planning. The external cost is the parameter or the basic unit, which can be used to directly compare the sectors since they contribute differently to different health impacts. The framework used in this study can be used as the basis for future regulatory action in emission reduction strategies. The main question we try to answer with this work is - which primary activities and emission sources are the greatest contributors to health-related externalities? More specifically, what are the relative contributions from ten major emission sectors in Europe and Denmark with respect to impacts on human health and related external costs?

Calculations developed to support regulatory actions in terms of emission control typically rely upon standardized source-receptor relationships, which are normally based on concentrations calculated with a CTM, such as the RAINS/GAINS system (Alcamo et al., 1990; Klaassen et al., 2004), as used by Amann et al. (2005) and Watkiss et al. (2005). However, such calculations rely on the assumption of a linear source-receptor relationship between emission changes and subsequent changes in air pollution lev- els. A slightly more sophisticated approach has also been applied in RAINS, where the linearity assumption has been substituted for a piecewise linear relationship for PM. For ozone the relationship may be parameterized using polynomials (Heyes et al., 1996). However, such assumptions are still approximations to the real response to emission reductions, not taking into account the full non-linear atmospheric chemistry, and are applied in order to save computing time. Non-linearity in the source-receptor relationship is particularly evident for certain atmospheric components, such as $\mathrm{NO}_{\mathrm{x}}, \mathrm{VOC}, \mathrm{O}_{3}, \mathrm{PM}, \mathrm{SO}_{2}$, and $\mathrm{NH}_{3}$.

The alternative approach, which we apply in this work, is to calculate the impacts from every emission scenario using comprehensive CTMs that explicitly include the highly non-linear chemical transformations and feedback mechanisms influencing air pollutants, using a tagging method (see Sect. 2.3). In this work, we explore the implications of using the three-dimensional, Eulerian CTM, DEHM (Danish Eulerian Hemispheric Model) to evaluate the external costs of air pollution. This is done within the integrated EVA model system (Economic Valuation of Air pollution; see Sect. 2.1) using estimates of exposure from DEHM (see Sect. 2.2). Other components of EVA are exposure-response functions and economic valuations of different health impacts. The exposure-response functions used in EVA, partly adapted from Watkiss et al. (2005) are based on assessments from experts in public health in the EU and in consultation with the WHO. The estimates of health costs rely on economic valuations appropriate for the European context. Using the EVA system, we estimate the health-related external costs in Europe and Denmark from the main emission sectors, represented by the 10 major emission sections (SNAP categories). In Sect. 2, a full description of the EVA model system is given, including the review of existing knowledge on particle toxicity. In Sect. 3, the simulations set up to answer the question defined above, are described and the results from the individual scenarios using the integrated EVA model system are presented. Section 4 includes the general results and discussions of the results, and Sect. 5 contains the overall conclusions of this work.

\section{The EVA model system}

In this section a description of the EVA model system is given. The section first presents an overview of the model system, and then a description of the individual modules in the system.

\subsection{Overview of the EVA model}

The concept of the EVA system (Frohn et al., 2006, 2007; Andersen et al., 2006, 2007a, 2008; Brandt et al., 2010, 2013) is based on the impact-pathway chain (e.g. Friedrich and Bickel, 2001; Krewitt, 1998), which is also used in the 


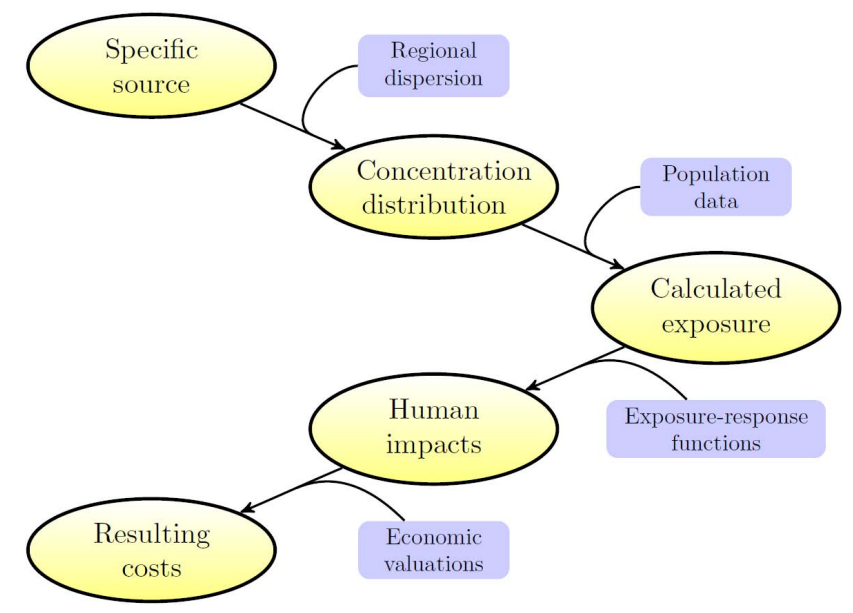

Fig. 1. A schematic diagram of the impact-pathway methodology. The site-specific emissions result (via atmospheric transport and chemistry) in a concentration distribution, which together with detailed population data, can be used to estimate the population-level exposure. Using exposure-response functions and economic valuations, the exposure can be transformed into impacts on human health and related external costs.

EcoSense model (ExternE, 1997, 1998, 1999, 2005). The concept is illustrated in Fig. 1. The EVA system consists of a regional-scale chemistry transport model, DEHM, addresslevel or gridded population data, exposure-response functions for health impacts and economic valuations of the impacts from air pollution. The system was originally developed to value site-specific health costs related to air pollution, such as from specific power plants (Andersen et al., 2006), but is in this work extended to assess health cost externalities for Europe and Denmark related to entire emission sectors.

The essential idea behind the EVA system is that the best available and most accurate yet computationally demanding methods are used in each part of the impact-pathway chain. The EVA system has the advantage that it describes non-linear processes using a comprehensive and thoroughly tested chemical transport model when calculating how specific changes in emissions affect air pollution levels. The geographic domain used in DEHM covers the Northern Hemisphere and, therefore, describes the intercontinental atmospheric transport, including higher resolution nesting over Europe (see Sect. 2.2 and Fig. 2). All scenarios are simulated individually and not estimated using linear interpolation or extrapolation from standard reductions, as used in the RAINS/GAINS system (Alcamo et al., 1990; Klaassen et al., 2004).

To estimate the effect of a specific emission source or emission sector, emission inventories for the specific sources are implemented in DEHM, together with all other relevant anthropogenic and natural emission sources.

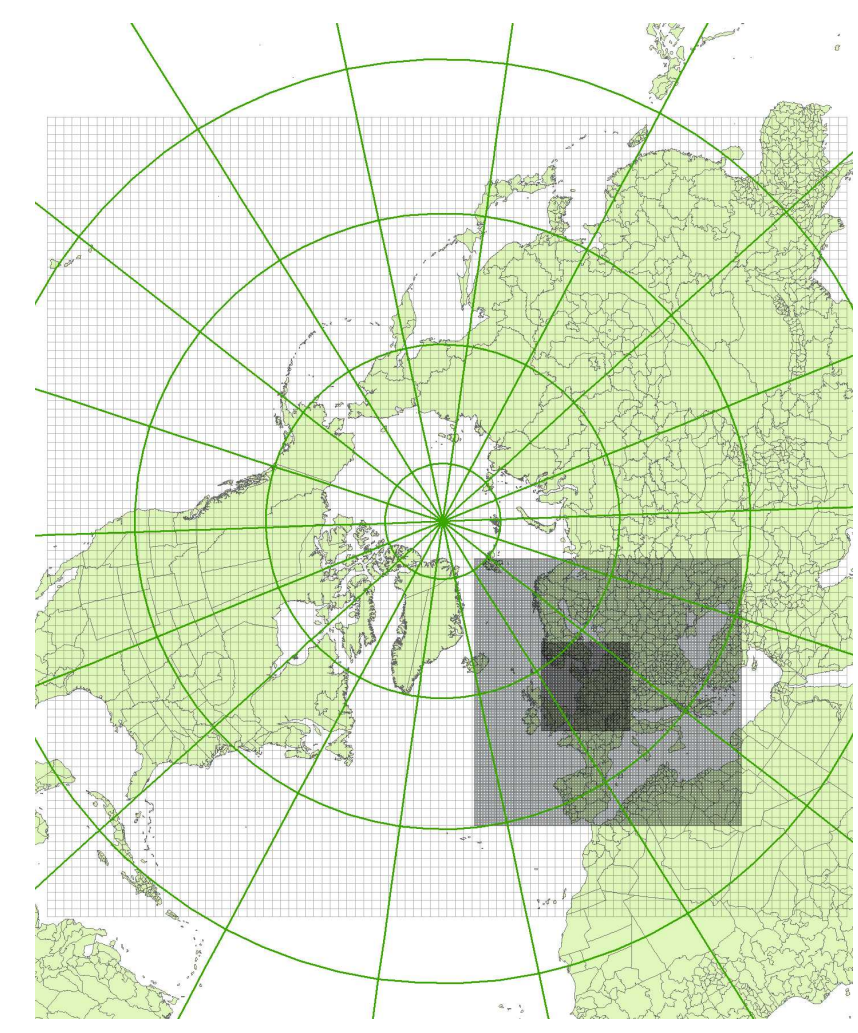

Fig. 2. The DEHM model domain (polar stereographic projection) with two nests. The mother domain covers the Northern Hemisphere with a resolution of $150 \mathrm{~km} \times 150 \mathrm{~km}$. The two nested domains included have resolution of $50 \mathrm{~km} \times 50 \mathrm{~km}$ (domain 2) and $16.67 \mathrm{~km} \times 16.67 \mathrm{~km}$ (domain 3), respectively.

However, quantifying the contribution from specific emission sources to the atmospheric concentration levels is a challenge. If the differences in concentrations due to the specific emissions of interest are relatively small, it is likely that these differences will be of the same order of magnitude as or smaller than the numerical noise from the CTM. To increase the reliability of the results and reduce the influence of this numerical noise when estimating $\delta$-function concentrations (i.e. the marginal difference in regional ambient concentration levels due to a specific emission source), we have implemented a "tagging" method (see Fig. 3 and Sect. 2.3). This method estimates source-receptor relationships and accounts for non-linear processes such as atmospheric chemistry, while maintaining a high signal-to-noise ratio. This method is much more accurate than taking the difference between two concentration fields, since the noise is proportional to the signal. Tagging methods have been used for specific species elsewhere with chemical transport models, (e.g. Pfister et al., 2008; Sudo and Akimoto, 2007). Here, however, we apply it to track the effects of the specific source for the full chemical scheme.

Estimates of $\delta$-concentrations are combined with addresslevel population data for Denmark and gridded population 
data for the rest of Europe, to calculate the exposure. Population-level health outcomes are estimated by combining population-level exposure with published exposureresponse functions. External costs for the entire population are estimated using cost functions customized for European conditions in the EVA model system.

\subsection{The Danish Eulerian Hemispheric Model}

The Danish Eulerian Hemispheric Model (DEHM) is a three-dimensional, offline, large-scale, Eulerian, atmospheric chemistry transport model (Christensen, 1997; Christensen et al., 2004; Frohn et al., 2001, 2002; Brandt et al., 2012) developed to study long-range transport of air pollution in the Northern Hemisphere and Europe. The model is routinely used for operational air pollution forecasting (Brandt et al., 2001a, b, c, 2003), for describing transport and fluxes of $\mathrm{CO}_{2}$ (Geels et al., 2002, 2004, 2007), transport of persistent organic pollutants (POPs) (Hansen et al., 2004, 2008a, b), atmospheric transport of pollen (Šikoparija et al., 2009) and impacts from climate change on future air pollution levels (Hedegaard et al., 2008, 2012, 2013). The model has lately been evaluated in several model intercomparisons and model ensemble studies (Vautard et al., 2009; Solazzo et al., 2012a, b, 2013). The model set-up used in this study includes three two-way nested domains discretized in $96 \times 96$ horizontal grids using a polar stereographic projection (Fig. 2). The mother domain covers most of the Northern Hemisphere, the second domain Europe and the third domain northern Europe. The horizontal grid resolutions for the coarse, medium and fine grids are $150 \mathrm{~km} \times 150 \mathrm{~km}, 50 \mathrm{~km} \times 50 \mathrm{~km}$, and $16.67 \mathrm{~km} \times 16.67 \mathrm{~km}$, respectively. The vertical grid is defined using the $\sigma$-coordinate system, with 20 vertical layers with the top of the model at $100 \mathrm{hPa}$, corresponding to $15-18 \mathrm{~km}$ altitude. The thickness of the lowest layer is $15-$ $20 \mathrm{~m}$. The model describes concentration fields of $58 \mathrm{chem}-$ ical compounds and 8 classes of particulate matter $\left(\mathrm{PM}_{2.5}\right.$, $\mathrm{PM}_{10}$, Total Suspended Particles (TSP), sea salt $<2.5 \mu \mathrm{m}$, sea salt $>2.5 \mu \mathrm{m}$, fresh black carbon, aged black carbon and organic carbon). A total of 122 chemical reactions are included. The model has been validated extensively, including a comparison with measurements from the whole of Europe (e.g. Brandt et al., 2012). The model is driven by meteorology from the MM5v3 meteorological model (Grell et al., 1994). Wet deposition is expressed as the product of scavenging coefficients and the concentration. Dry deposition is solved separately for gases and particles, and deposition rates depend on the land cover.

Emissions are based on several inventories, including EDGAR (Olivier and Berdowski, 2001), GEIA (Graedel et al., 1993), retrospective wildfires (Schultz et al., 2008), ship emissions both around Denmark (Olesen et al., 2009) and globally (Corbett and Fischbeck, 1997), and emissions from the EMEP database (Mareckova et al., 2008). For ozone, the initial and boundary conditions are based on ozonesonde measurements, interpolated to global monthly 3-D values with a resolution of $4^{\circ} \times 5^{\circ}$ (Logan, 1999). The exchange between the stratosphere and troposphere is taken into account. For a more detailed description of the DEHM model, see Brandt et al. (2012).

With respect to emissions from natural sources, emissions from retrospective wildfires are included based on Schultz et al. (2008). The current version of DEHM includes the temporal allocation of emissions from the IGAC-GEIA biogenic emission model for biogenic isoprene (International Global Atmospheric Chemistry-Global Emission Inventory Activity; Guenther et al., 1995) as an in-line module. This module is presently being replaced by the Model of Emissions of Gases and Aerosols from Nature (MEGAN) (Guenther et al., 2006; Zare et al., 2012), also including a module for the formation of secondary organic aerosols (SOAs) (Zare et al., 2013). However, these implementations were not available for the present study. Natural emissions of $\mathrm{NO}_{\mathrm{x}}$ from lightning and soil as well as emissions of $\mathrm{NH}_{3}$ from soil/vegetation based on GEIA are also implemented in the model.

\subsection{The tagging method}

In order to calculate the contributions from a specific emission source or sector to the overall air pollution levels (the $\delta$ concentrations), two model runs (simulations using a CTM) can be carried out: one including all emissions and one including all emissions minus the specific emissions of interest. Estimated yearly mean concentrations from the latter model run are subtracted from those of the first simulation, and the resulting difference provides an estimate of the contribution of the specific emission sources of interest to the total air pollution levels. The difference between the two resulting annual mean concentration fields gives an estimate of the $\delta$ concentration - we will call this the subtraction method for estimating $\delta$-concentrations.

Modern Eulerian CTMs rely on higher order numerical methods for solving the atmospheric advection in order to avoid numerical diffusion. Although higher order algorithms are relatively accurate, they nevertheless introduce a certain amount of spurious oscillations or numerical noise - this is called the Gibbs phenomenon (e.g. Brandt et al., 1996). These unwanted oscillations can cause major problems for estimating $\delta$-concentrations applying the subtraction method. Through a number of experiments, we have found that the $\delta$ concentrations may be of similar or even smaller order of magnitude compared to the numerical oscillations.

To avoid this problem, we implemented a more accurate method for comparing concentrations from two sets of emission fields. We call this method "tagging", implying that we keep track of contributions to the concentration field from a particular emission source or sector. An overview of this method is given in Fig. 3. The idea is that we model the $\delta$ concentrations explicitly, rather than calculating them post 


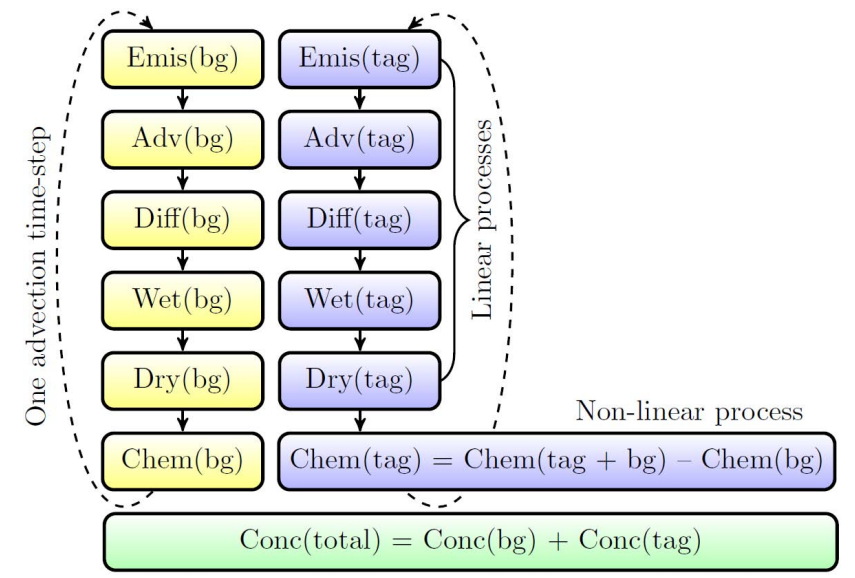

Fig. 3. An overview of the tagging method. The concentration field for a specific emission source (tag) is modelled in parallel with the background field (bg) in the CTM. The need for tagging is due to the non-linear process of atmospheric chemistry (Chem). The linear processes are emissions (Emis), advection (Adv), atmospheric diffusion (Diff), wet deposition (Wet), and dry deposition (Dry). For the non-linear process, the tagged concentration fields are estimated by first adding the background and tag concentration fields, then applying the non-linear operator (e.g. the chemistry). The concentration field obtained by applying the non-linear operator to the background field alone is then subtracted. Thus the contribution from the specific emission source is accounted for appropriately without assuming linearity of the non-linear atmospheric chemistry.

hoc (i.e. by subtraction). Tagging makes use of the fact that the numerical noise is typically proportional to the concentrations and gradients being modelled. In the case of the subtraction method, the numerical noise is associated with the concentrations of two model runs where the annual mean concentrations typically are much larger than the $\delta$ concentrations of interest (given by the difference between the annual means). Using the subtraction method, the magnitude of the numerical noise for each model result can therefore be much larger than the difference between the two results (i.e. the $\delta$-concentrations). In the case where the tagging method is used, the numerical noise is proportional to the $\delta$ concentrations and not to the background concentrations and is therefore much smaller. Even if the $\delta$-concentrations are much smaller than the background concentrations, the numerical noise will be even smaller. Consequently, estimates of the $\delta$-concentrations are much more accurate using the tagging method.

Tagging involves modelling the background concentrations and the $\delta$-concentrations in parallel. Special treatment is required for the non-linear process of atmospheric chemistry, since the $\delta$-concentrations are strongly influenced by the background concentrations in such processes; although this treatment involves taking the difference of two concentration fields, it does not magnify the spurious oscillations, which are primarily generated in the advection step. Thereby the non-linear effects (e.g. from the background chemistry) can be accounted for in the $\delta$-concentrations without losing track of the contributions arising from the specific emission source or sector due to Gibbs phenomenon.

Tagging has one major disadvantage compared to the subtraction method: it requires that the two simulations are run simultaneously in the CTM, thereby doubling the memory requirements and the computational time compared to the subtraction method. Furthermore, results from the tagging method require more storage space compared to the subtraction method. These disadvantages must be weighed against the increased accuracy. Since present-day computing, memory and storage costs are relatively low, a high number of simulations is not insurmountable, especially if the code is suitably parallelized.

\subsection{Population data}

Denmark has a central registry, detailing the address, gender and age of every person in Denmark (the Central Person Register). Data from this database were extracted for the year 2000 , chosen as the base year for the EVA system. Address data were interpolated to the DEHM grid to obtain gridded population data. For each grid cell, the number of persons of each age and gender was aggregated, as a first step towards estimating population-weighted exposure. On the European scale, a gridded data set was obtained from EMEP (www.emep.int), covering the whole of Europe (DEHM domain 2). The EVA system is not applied outside of Europe in this work, and therefore population data for the rest of the world are not included.

\subsection{Exposure-response functions and monetary values}

To calculate the impacts of emissions from a specific source or sector, $\delta$-concentrations and address-level population data are combined to estimate human exposure, and then the response is calculated using an exposure-response function (ERF) of the following form:

$R=\alpha \cdot \delta c \cdot P$,

where $R$ is the response (e.g. in cases, days, or episodes), $\delta c$ the $\delta$-concentration (i.e. the additional concentration resulting from emissions of a particular emission source), $P$ the affected share of the population, and $\alpha$ an empirically determined constant for the particular health outcome, typically obtained from published cohort studies. In this study, we model the exposure-response relationship as a linear function. Pope et al. (2000) showed that this is a reasonable approximation, based on a cohort study of 500000 individuals, and this is also supported by the joint World Health Organization/UNECE Task Force on Health (EU, 2004; Watkiss et al., 2005). The exposure-response relations and valuations used in the EVA system (Table 1) are applicable for European conditions. All the exposure-response functions displayed 
in Table 1 have recently been reviewed; see Bønløkke et al. (2011).

All relevant chemical compounds (i.e. those endorsed by the WHO and the EU Commission) are included in the study. For compounds in aerosol phase, the impacts are assumed to be proportional to their contribution to the particle mass, as opposed to the number of particles. Presently, the compounds related to human health impacts included in the EVA system are $\mathrm{O}_{3}, \mathrm{CO}, \mathrm{SO}_{2}, \mathrm{SO}_{4}^{2-}, \mathrm{NO}_{3}^{-}$, and the primary emitted part of $\mathrm{PM}_{2.5} . \mathrm{NH}_{4}^{+}$is furthermore included when it is contributing to the particle mass by reactions with sulfate or nitrate.

\subsubsection{Mortality}

Following conclusions from the scientific review of the CAFE appraisal (Hurley et al., 2005; Krupnick et al., 2005), we base the exposure-response function (ERF) for chronic mortality (defined below) in response to long-term $\mathrm{PM}_{2.5}$ exposure on the findings of Pope et al. (2002), which is the most extensive study available. The results are supported by a re-analysis of the original data applying alternative and extensive statistical analyses (Krewski et al., 2009).

Chronic mortality refers to mortality risks associated with long-term exposure. The number of lost life years for a Danish population cohort with normal age distribution, when applying the ERF of Pope et al. (2002) for all-cause mortality (relative risk, $\mathrm{RR}=1.06$ ), and the latency period indicated, sums to $1138 \mathrm{yr}$ of life lost (YOLL) per 100000 individuals for an annual $10 \mu \mathrm{g} \mathrm{PM}_{2.5} \mathrm{~m}^{-3}$ increase (Andersen, 2008).

While the ERF for chronic mortality is derived from cohort studies, numerous time-series studies have shown that air pollution exposure also may cause acute effects. Because acute deaths are valued differently from chronic deaths (see valuation section below), it is necessary to quantify these separately (OECD, 2006). It has also been established that $\mathrm{O}_{3}$ concentrations above the level of $35 \mathrm{ppb}$ involve an acute mortality increase, presumably for weaker and elderly individuals. We apply the ERFs selected in CAFE for post-natal death (age group 1-12 months) and acute death related to $\mathrm{O}_{3}$ (Hurley et al., 2005). Finally, there are studies that have shown that $\mathrm{SO}_{2}$ is associated with acute mortality, and for this response we apply the ERF identified in the APHEA study - Air Pollution and Health: A European Approach (Katsouyanni et al., 1997).

\subsubsection{Morbidity}

Chronic exposure to $\mathrm{PM}_{2.5}$ is associated with morbidity. For instance, this is the case for lung cancer, and we apply the specific ERF ( $R R=1.08$ per $10 \mu \mathrm{g} \mathrm{PM}_{2.5} \mathrm{~m}^{-3}$ increase) for lung cancer indicated in Pope et al. (2002) as a basis for calculating the morbidity costs associated with lung cancer incidents.

The prevalence of the chronic disease bronchitis has been shown to increase with chronic exposure to $\mathrm{PM}_{2.5}$. We apply an ERF (RR = 1.007) for new cases of bronchitis based on the AHSMOG study (involving non-smoking Seventh-Day Adventists; Abbey et al., 1999), the same epidemiological study as in CAFE (Abbey, 1995; Hurley et al., 2005). The ExternE crude incidence rate was chosen as a background rate (ExternE, 1999), which is in agreement with a Norwegian study, rather than the pan-European estimates used in CAFE (Eagan et al., 2002).

Restricted activity days (RADs) comprise two types of responses to exposure: so-called minor restricted activity days as well as work-loss days. This distinction enables accounting for the different costs associated with days of reduced well-being and actual sick days. It is assumed that $40 \%$ of RADs are work-loss days. The background rate and incidence are derived from ExternE (1999). Hospital admissions are deducted to avoid any double counting. Hospital admissions and health effects for asthmatics (here corresponding to the three responses bronchodilator use, cough and lower respiratory symptoms) are also based on ExternE (1999).

\subsubsection{Valuation}

OECD guidelines for environmental cost-benefit analysis (OECD, 2006) address the complex debate on valuation of mortality (see also Nielsen et al, 2010). It is not human life per se that is valued, but the willingness to pay for preventing risks of fatalities. Whereas in transport economics it has become customary to employ a value of statistical life (VSL), environmental economics has applied a different valuation by developing the metric of value of a life year lost (VOLY). In part, this is due to the difference between transport victims, who are often mid-age, and victims of environmental exposures, who tend to be more elderly (as a result of latency time lag and chronic exposures). Hence fewer life years are assumed lost per individual as a result of environmental exposures.

OECD guidelines recommend applying a VSL approach to valuation for acute mortality and a VOLY approach for chronic mortality. Acute mortality in this setting is defined as immediate increases in mortality as a result of short-term peaks in exposure (i.e. hours to days), whereas chronic mortality is defined as increases in annual mortality associated with increased levels of exposure over long periods of time. However, while a degree of consensus has emerged over estimates of VSL, in part because of the rich literature published over the past decades, the estimates used for a VOLY are based on relatively few studies. An expert panel gathered by the European Commission (2001) agreed on a consensus estimate of 1.4 million euros for an EU-wide VSL, an update essentially on the original Jones-Lee study (1985). Alberini et al. (2006) derived a VOLY estimate of 54000 euros from a three-nation study, which was used as a basis for the CAFE assessment. With the VOLY of 54000 euros approximately 27 VOLYs equals a full VSL of 1.4 million euros. In Denmark the average age for a traffic accident victim is $45-48$, 
Table 1. Health effects, exposure-response functions and economic valuation (applicable for Danish/European conditions) currently included in the EVA model system. (PM is particulate matter, including primary $\mathrm{PM}_{2.5}, \mathrm{NO}_{3}^{-}$and $\mathrm{SO}_{4}^{2-}$. YOLL is years of life lost. SOMO35 (Sum of Ozone Means Over $35 \mathrm{ppb}$ ) is the sum of means over $35 \mathrm{ppb}$ for the daily maximum 8-hour values of ozone).

\begin{tabular}{|c|c|c|}
\hline Health effects (compounds) & Exposure-response coefficient $(\alpha)$ & Valuation, euros (2006 prices) \\
\hline \multicolumn{3}{|c|}{ Morbidity } \\
\hline Chronic bronchitis (PM) & $8.2 \times 10^{-5}$ cases $/ \mu \mathrm{g} \mathrm{m}^{-3}$ (adults) & 52962 per case \\
\hline Restricted activity days (PM) & $\begin{array}{l}=8.4 \times 10^{-4} \text { days } / \mu \mathrm{g} \mathrm{m}^{-3} \text { (adults) } \\
-3.46 \times 10^{-5} \text { days } / \mu \mathrm{g} \mathrm{m}^{-3} \text { (adults) } \\
\left.-2.47 \times 10^{-4} \text { days } / \mu \mathrm{g} \mathrm{m}^{-3} \text { (adults }>65\right) \\
-8.42 \times 10^{-5} \text { days } / \mu \mathrm{g} \mathrm{m}^{-3} \text { (adults) }\end{array}$ & 131 per day \\
\hline $\begin{array}{l}\text { Congestive heart failure (PM) } \\
\text { Congestive heart failure (CO) }\end{array}$ & $\begin{array}{l}3.09 \times 10^{-5} \text { cases } / \mu \mathrm{g} \mathrm{m}^{-3} \\
5.64 \times 10^{-7} \text { cases } / \mu \mathrm{g} \mathrm{m}^{-3}\end{array}$ & 16409 per case \\
\hline Lung cancer (PM) & $1.26 \times 10^{-5}$ cases $/ \mu \mathrm{g} \mathrm{m}^{-3}$ & 21152 per case \\
\hline \multicolumn{3}{|c|}{ Hospital admissions } \\
\hline $\begin{array}{l}\text { Respiratory }(\mathrm{PM}) \\
\text { Respiratory }\left(\mathrm{SO}_{2}\right)\end{array}$ & $\begin{array}{l}3.46 \times 10^{-6} \text { cases } / \mu \mathrm{g} \mathrm{m}^{-3} \\
2.04 \times 10^{-6} \text { cases } / \mu \mathrm{g} \mathrm{m}^{-3}\end{array}$ & 7931 per case \\
\hline Cerebrovascular (PM) & $8.42 \times 10^{-6}$ cases $/ \mu \mathrm{g} \mathrm{m}^{-3}$ & 10047 per case \\
\hline \multicolumn{3}{|c|}{ Asthma, children $(7.6 \%<16 \mathrm{yr})$} \\
\hline $\begin{array}{l}\text { Bronchodilator use (PM) } \\
\text { Cough (PM) } \\
\text { Lower respiratory symptoms (PM) }\end{array}$ & $\begin{array}{l}1.29 \times 10^{-1} \text { cases } / \mu \mathrm{g} \mathrm{m}^{-3} \\
4.46 \times 10^{-1} \text { days } / \mu \mathrm{g} \mathrm{m}^{-3} \\
1.72 \times 10^{-1} \text { days } / \mu \mathrm{g} \mathrm{m}^{-3}\end{array}$ & $\begin{array}{l}23 \text { per case } \\
59 \text { per day } \\
16 \text { per day }\end{array}$ \\
\hline \multicolumn{3}{|c|}{ Asthma, adults $(5.9 \%$ > 15 yr) } \\
\hline $\begin{array}{l}\text { Bronchodilator use (PM) } \\
\text { Cough }(\mathrm{PM}) \\
\text { Lower respiratory symptoms (PM) }\end{array}$ & $\begin{array}{l}2.72 \times 10^{-1} \text { cases } / \mu \mathrm{g} \mathrm{m}^{-3} \\
2.8 \times 10^{-1} \text { days } / \mu \mathrm{g} \mathrm{m}^{-3} \\
1.01 \times 10^{-1} \text { days } / \mu \mathrm{g} \mathrm{m}^{-3}\end{array}$ & $\begin{array}{l}23 \text { per case } \\
59 \text { per day } \\
16 \text { per day }\end{array}$ \\
\hline \multicolumn{3}{|c|}{ Loss of IQ } \\
\hline $\begin{array}{l}\text { Lead }(\mathrm{Pb})(<3 \text { year })^{*} \\
\text { Mercury }(\mathrm{Hg}) \text { (foetus) }\end{array}$ & $\begin{array}{l}1.3 \text { points } / \mu \mathrm{g} \mathrm{m}^{-3} \\
0.33 \text { points } / \mu \mathrm{g} \mathrm{m}^{-3}\end{array}$ & $\begin{array}{l}24967 \text { per point } \\
24967 \text { per point }\end{array}$ \\
\hline \multicolumn{3}{|c|}{ Mortality } \\
\hline $\begin{array}{l}\text { Acute mortality }\left(\mathrm{SO}_{2}\right) \\
\text { Acute mortality }\left(\mathrm{O}_{3}\right)\end{array}$ & $\begin{array}{l}7.85 \times 10^{-6} \text { cases } / \mu \mathrm{g} \mathrm{m}^{-3} \\
3.27 \times 10^{-6 *} \mathrm{SOMO} 35 \text { cases } / \mu \mathrm{g} \mathrm{m}^{-3}\end{array}$ & 2111888 per case \\
\hline $\begin{array}{l}\text { Chronic mortality, YOLL (PM) } \\
\text { Infant mortality (PM) }\end{array}$ & $\begin{array}{l}1.138 \times 10^{-3} \mathrm{YOLL} / \mu \mathrm{g} \mathrm{m}^{-3}(>30 \mathrm{yr}) \\
6.68 \times 10^{-6} \text { cases } / \mu \mathrm{g} \mathrm{m}^{-3}(>9 \text { months })\end{array}$ & $\begin{array}{l}77199 \text { per YOLL } \\
3167832 \text { per case }\end{array}$ \\
\hline
\end{tabular}

* Exposure-response function for $\mathrm{Pb}$ and $\mathrm{Hg}$ are included in the EVA system (Pizzol, 2010). However, they are not included in these studies.

with the implication that on average the number of years lost is 27-30. Hence there is reasonable consistency with the VSL-VOLY factor of 27, if one assumes that preferences for risk aversion are correlated with remaining life expectancy. It could be a bold assumption, as certain studies indicate that preferences for risk aversion may change with age more according to a reverse U-curve, but due to very few respondents these results can be questioned. For our purposes we may nevertheless note that the approach recommended in OECD guidelines is conservative and does not result in upper-bound estimates of willingness to pay for risk aversion.

The position of the European Commission has been to use the same unit values for VSL and VOLY across the European Union, although incomes and presumably willingness to pay for risk reductions vary considerably. The reviewers of the CAFE cost-benefit analysis made note of these inconsistencies and recommended weighing risk aversions with purchasing power coefficients of different member states. In this study, we have used the PPP (purchasing power parities - a 
technique used to determine the relative value of currencies) for Denmark. Hence values of VOLY and VSL in 2006 prices are 77 euros and 2.1 million euro, respectively.

For morbidity effects and in the absence of original Danish contingent valuation studies, we have opted for a cost-ofillness approach. For hospital admissions, for instance, unit costs are available in the diagnosis-related groups (DRGs) database of the National Board of Health. Still, "cough" and "lower respiratory symptoms" are based on willingness to pay (WTP) benefit transfer. Chronic bronchitis is the result of cost-of-illness calculations. The exposure-response coefficients and the related valuation for morbidity and mortality used in the EVA system are summarized in Table 1.

\subsection{Health effects from particles}

The health effects related to particulate matter (PM) are the most extensively used in the literature, and their costs become dominant compared to the other species. Therefore, it is important to include a smaller review about our knowledge concerning this issue. A recent study indicated that worldwide 3.1 million deaths are attributable to ambient PM annually (Lim et al., 2012). In Denmark, previous estimates have suggested that roughly 3000-4000 people die prematurely every year due to present levels of atmospheric pollution (Raaschou-Nielsen et al., 2002). Both the EU and WHO provide directives/guidelines for limit values of PM and ozone concentrations to minimize impacts on human health (EU, 2008; WHO, 2006a). Support of adverse health effects of PM is also found in a long range of laboratory, animal and human experimental studies. Associations between PM and mortality have been demonstrated in studies of both shortterm (e.g. Maynard et al., 2007) and long-term population exposure (i.e. cohort studies). Cohort studies form the basis of the ERF used for calculation of chronic mortality. In addition to the American Cancer Society study (Pope et al., 1995, 2002, 2009; Krewski et al., 2000, 2009) and the Harvard Six Cities Study (Dockery et al., 1993; Laden et al., 2006), the most commonly cited cohort studies, a series of other cohort studies have been published (e.g. Jerrett et al., 2005; Abbey et al., 1999; Enstrom et al., 2005; Filleul et al., 2005; Pelucchi et al., 2009) strongly corroborating the link between longterm exposure to PM and adult mortality.

Atmospheric PM is considered responsible for increased mortality and morbidity, primarily via cardiovascular and respiratory diseases (Schlesinger et al., 2006). In recent years a number of studies have demonstrated associations with mortality (e.g. Yap et al., 2012) and morbidity from specific cardiovascular diseases (e.g. Schwartz et al., 2012). For cost calculations based on years of lives lost or number of fatalities, the specific associations are of less use than associations with all-cause mortality as the former have not been studied in sufficient detail to sum up to the total as observed by, for example, Pope et al. (2002). In addition to these diseases and as described previously to cough, infant mortality, restricted activity, and work-loss days, PM has been found to be associated with a range of health outcomes, for example, diabetes (Pearson et al., 2010) and low birth weight (Liu et al., 2007). Several studies indicate that the effects of PM could depend on the source of the PM or regions from where it is emitted (e.g. Franklin et al., 2008; Bell et al., 2009). No simple pattern, however, has emerged on which sources or which PM constituents matter the most. Based on long-term cohort studies, the evidence of links between health effects and the sulfate fraction of particles (Pope et al., 2002) is good. In contrast, the nitrate fraction has not been associated as strongly with health effects in such studies, or correlations with other compounds have not been excluded as contributing to the effects of nitrate (Ostro et al., 2010). Several smaller epidemiological studies and experimental studies have separated exposure to particulate matter into the chemical compounds of the particles and often found that metals show the strongest associations (Franklin et al., 2007). Although source apportionment studies in recent years commonly have associated health effects with transition metals, some have also found effects associated with sulfates (Zanobetti et al., 2009; Franklin et al., 2008) or nitrates (Ostro et al., 2007; Andersen et al., 2007b) or potassium (from wood combustion) (Ostro et al., 2010). Even the ammonium ion has, at least in one study (Peng et al., 2009), been associated with cardiovascular disease although the finding was not statistically significant. A problem of interpreting such source-specific associations is that many compounds are closely correlated and that different outcomes and time lags appear in the literature.

Despite the discrepancy in the observations on which PM constituents contribute the most to health effects, some (but not all) investigators argue that it is reasonable to attribute greater risks to primary particles than to secondary (Andersson et al., 2009; Jerrett et al., 2005). This is based on the higher risks seen in studies based on intra-city exposure gradients compared to inter-city exposure. Andersson et al. (2009) argue that epidemiological studies, which have found associations of nitrogen oxides as proxies for primary vehicle exhaust exposure, also indicate that a higher relative risk than 1.06 should be applied for primary particulates.

The problem of how to estimate health effects of secondary particles has been addressed differently in previous air pollution externality models. ExternE $(1997,2005)$ made a distinction between the effects of nitrates and sulfates based on the argumentation that nitrates need other particles to condense on, whereas sulfates self-nucleate and therefore are smaller particles on average. Along this line of argumentation, sulfates were treated like $\mathrm{PM}_{2.5}$ and nitrates like $\mathrm{PM}_{10}$. In the NEEDS report (NEEDS, 2007), sulfate and nitrate particles were quantified insofar as they contributed to the total particulate matter concentration. As a sensitivity analysis, they proposed treating primary particles at 1.3 times the toxicity of the $\mathrm{PM}_{2.5}$ mixture and secondary particles at 0.7 times the toxicity of $\mathrm{PM}_{2.5}$. In DEFRA (2007) the same hazard rate 
Table 2. Definition of the specific scenarios (or "tags" in the model). Each scenario is defined by a region - either Europe (EU) or Denmark (DK), SNAP category (first column) and a short description of the emissions of interest in the scenario. The scenarios are either run for emissions covering the whole of Europe (DEHM domain 2) or Denmark.

\begin{tabular}{|c|c|c|}
\hline Region & SNAP & Emission scenario (or the "tag") \\
\hline \multirow{12}{*}{ EU/DK } & 1 & Combustion in energy and transformation industries \\
\hline & 2 & Non-industrial combustion plants, including private wood combustion \\
\hline & 3 & Combustion in manufacturing industry \\
\hline & 4 & Production processes \\
\hline & 5 & Extraction and distribution of fossil fuels and geothermal energy \\
\hline & 6 & Solvents and other product use \\
\hline & 7 & Road transport \\
\hline & 8 & Other mobile sources and machinery (excl. international ship traffic) \\
\hline & 9 & Waste treatment and disposal \\
\hline & 10 & Agriculture \\
\hline & Sum $1-10$ & Sum of the above 10 SNAP categories \\
\hline & All & All anthropogenic emissions (SNAP 1-SNAP 10) \\
\hline
\end{tabular}

for long-term mortality was used for all particle components. The same approach was chosen in The Clean Air for Europe (CAFE) Programme (Holland et al., 2005), but sensitivity analyses were conducted by assigning different toxicities to primary particles, sulfates and nitrates.

Thus the choice in this study - to assign equal health effect to all components of particles - is in line with other recent major reports. This is also supported in a recent paper by Rohr and Wyzga (2012) that reviewed the literature on fine particulate matter components and health effects. They found that no components show unequivocal evidence of zero health impact and that the carbon-containing PM appears to be most strongly associated with health effects. In addition we performed a sensitivity study in order to assess the effects of assigning different toxicities to primary emitted (e.g. BC and OC) and secondary formed particles, with factors of 1.3 and 0.7 , respectively.

\section{Definition of model simulations}

In this section, a number of model simulations are defined in order to answer the questions (Sect. 3.1), and an example of a tagged model run for Denmark is presented. The overall results will be presented and discussed in Sect. 4. All model simulations are driven by meteorological data for the year 2000, calculated using the MM5v3 model (Grell et al., 1994).

All results that follow are given as human health impacts and external costs, both for the whole of Europe and for Denmark specifically - the latter being part of the former. When making decisions about regulation of specific emission sectors, it is important to consider all impacts from the emission sources of interest from all affected countries. However, national interests can also be important, and therefore the human health impacts and the associated fraction of the total external costs are also given for Denmark alone as an example of a national assessment.

To answer the overall question given in the introduction, a number of different scenarios have been defined in order to estimate health-related externalities from different kinds of emission sources (see Table 2). Each scenario is defined by three attributes. (1) The region is where the emission sources are located. In this work, the regions are Europe (EU; corresponding to the whole European domain 2 in DEHM) or Denmark (DK). (2) The emission sectors are defined using the Selected Nomenclature for Air Pollution (i.e. the SNAP categories). The ten major anthropogenic SNAP categories are defined in Table 2. (3) The emission year is the last one. The base emission year has been chosen to be year 2000 . This has been the base year in many other studies (e.g. the CAFE studies), and it is therefore easier to compare the results in this work to other studies. Furthermore, some results for Denmark are given for the year 2008 to evaluate the development over time due to changes in both the emissions and the relative distribution between emission sectors.

Model simulations (EU/1-EU/10 or DK/1-DK/10 - see Table 2) are defined for the ten major emission sectors either for Europe (EU) or Denmark (DK). The scenarios including all anthropogenic emissions in Europe or Denmark (EU/all or DK/all) are defined in order to compare the results obtained from the sum of scenarios 1-10 with results obtained running all anthropogenic emissions simultaneously. The scenarios named EU/1-10 and DK/1-10 are the sum of the results obtained in scenarios EU/1 to EU/10 and DK/1 to $\mathrm{DK} / 10$, respectively. If the impact on ambient air pollution levels from emission reductions were linear, the results from, for example, scenarios DK/1-10 and DK/all would be the same. However, the source-receptor relationships are nonlinear due to the effects of atmospheric chemistry, and therefore the scenarios DK/1-10 and DK/all are not expected to 
Table 3. Total number of cases of the different impacts related to all Danish anthropogenic emissions (scenario: all) for the year 2000.

\begin{tabular}{lcc}
\hline Health impact & Number of cases in Europe & Number of cases in Denmark \\
\hline Chronic bronchitis & 4350 & 802 \\
Restricted activity days & 4440000 & 820000 \\
Respiratory hospital admissions & 234 & 44 \\
Cerebrovascular hospital admissions & 556 & 101 \\
Congestive heart failure & 324 & 69 \\
Lung cancer & 666 & 123 \\
Bronchodilator use, children & 128000 & 21600 \\
Bronchodilator use, adults & 851000 & 157000 \\
Cough, children & 441000 & 74600 \\
Cough, adults & 876000 & 162000 \\
Lower respiratory symptoms, children & 170000 & 52800 \\
Lower respiratory symptoms, adults & 316000 & 58300 \\
Acute mortality & 85 & -9 \\
Chronic mortality (YOLL) & 49000 & 8520 \\
Infant mortality & 5 & 1 \\
\hline
\end{tabular}

be equal. The impact from the non-linear atmospheric chemistry depends very much on the chemical regime in the region of interest and on the size of the emission reductions, and it is therefore not possible a priori to estimate the difference between the sum of the 10 scenarios and the simulation where all 10 scenarios are run simultaneously.

As an example of the DEHM model results, Fig. 4 shows the contribution to the mean annual air pollution levels $(\delta$ concentrations) due to the emissions from the whole of Denmark for all SNAP categories (i.e. 1 to 10 simultaneously). Results are given for the six chemical compounds included in EVA $\left(\mathrm{SO}_{2}, \mathrm{SO}_{4}^{2-}, \mathrm{CO}\right.$, primary $\mathrm{PM}_{2.5}, \mathrm{NO}_{3}^{-}$and $\left.\mathrm{O}_{3}\right)$ for the year 2000. Results are shown for the DEHM domain 3 (northern Europe) and correspond to the scenarios DK/all in Table 2. The results for ozone $\left(\mathrm{O}_{3}\right)$ show that $\mathrm{NO}_{\mathrm{x}}$ emissions in Denmark contribute to both a decrease and an increase in the ozone levels in different areas. This is because the typical effect of the $\mathrm{NO}_{\mathrm{x}}$ emissions is a decrease in the ozone levels in the source area (in this case Denmark) and nearby. Downwind from the source, the typical effect of the $\mathrm{NO}_{\mathrm{x}}$ emissions is an increase in the ozone concentration levels. This is a well-known non-linear effect, where the chemical production or loss of ozone depends on the chemical regime meaning the concentrations of the ozone precursors.

\section{Results and discussions}

The main objective of this work is to make an assessment of the contribution to health-related externalities of air pollution from the major emission categories. In Sect. 4.1 an example of the health impacts is presented. In Sect. 4.2, the total health-related externalities are given.
Table 4. The total external costs in million euros per chemical compound for the whole of Europe from anthropogenic Danish emission sectors for the year 2000. Total $\mathrm{S}$ is the sum of the external cost of $\mathrm{SO}_{2}$ and $\mathrm{SO}_{4}^{2-}$. Total $\mathrm{N}$ is the sum of the external costs of $\mathrm{O}_{3}$ and $\mathrm{NO}_{3}^{-}$. The external costs from $\mathrm{NH}_{3}$ emissions are included in the impacts related to $\mathrm{S}$ and $\mathrm{N}$ through chemical reactions in the atmosphere.

\begin{tabular}{llrrrr}
\hline Region/SNAP & CO & Total S & Total N & PM $_{2.5}$ & Sum \\
\hline DK/1 & 0.005 & 148 & 420 & 15 & 583 \\
DK/2 & 0.123 & 82 & 125 & 324 & 531 \\
DK/3 & 0.009 & 92 & 183 & 26 & 301 \\
DK/4 & 0.001 & 43 & 57 & 10 & 110 \\
DK/5 & 0.002 & 35 & 62 & 1.3 & 98 \\
DK/6 & 0.009 & 56 & 95 & 0.04 & 151 \\
DK/7 & 0.359 & 33 & 758 & 208 & 999 \\
DK/8 & 0.089 & 31 & 336 & 80 & 447 \\
DK/9 & 0.000 & 0.3 & 32 & 0.2 & 32 \\
DK/10 & 0.001 & 1000 & 1390 & 32 & 2422 \\
Sum: DK/1-10 & 0.598 & 1520 & 3460 & 697 & 5678 \\
DK/All & 0.593 & 1300 & 2920 & 704 & 4925 \\
\hline
\end{tabular}

\subsection{Health impacts}

Table 3 displays the number of cases in Europe and Denmark related to the different impacts due to all Danish anthropogenic emissions (scenario: DK/all) for the year 2000 (corresponding to the results in Fig. 4). As can be seen in Table 3, the number of cases in Denmark for acute mortality is negative. This is because the $\mathrm{NO}_{\mathrm{x}}$ emissions in Denmark actually cause a decrease in the ozone levels within Denmark (see also the lower right figure in Fig. 4). The chronic mortality (given as YOLL) caused by anthropogenic Danish emissions is approx. 49000 in Europe and approx. 8500 in Denmark. In the CAFE calculations (Watkiss et al., 2005), a 

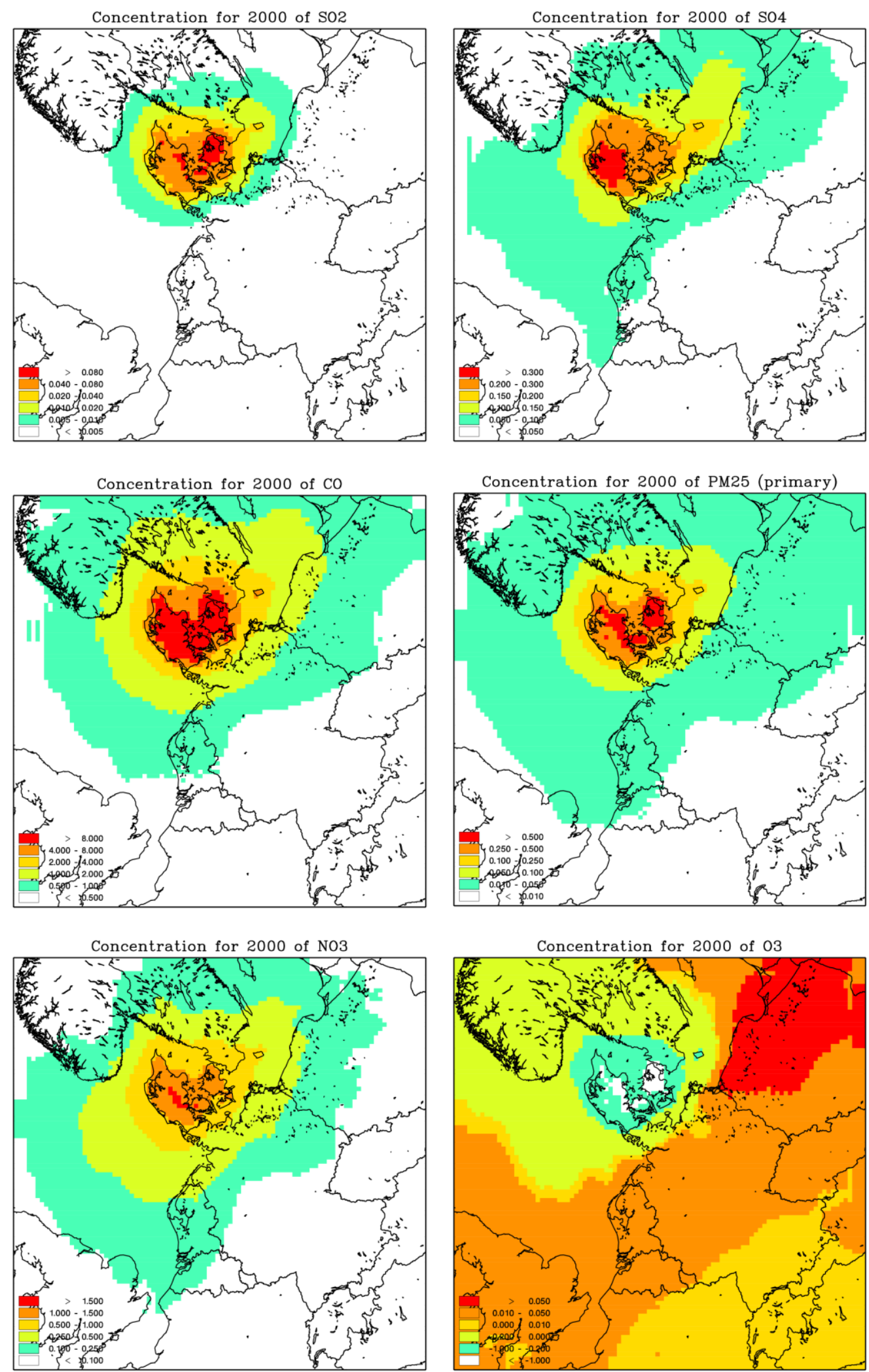

Fig. 4. Contribution to the mean annual air pollution levels ( $\delta$-concentrations) calculated using the DEHM model due to emissions from the whole of Denmark for all SNAP categories 1 to 10 simultaneously, for the year 2000. The compounds are $\mathrm{SO}_{2}[\mathrm{ppb}], \mathrm{SO}_{4}^{2-}\left[\mu \mathrm{g} \mathrm{m}^{-3}\right], \mathrm{CO}$ [ppm], $\mathrm{PM}_{2.5}$ (primary part) $\left[\mu \mathrm{g} \mathrm{m}^{-3}\right], \mathrm{NO}_{3}^{-}\left[\mu \mathrm{g} \mathrm{m}^{-3}\right]$ and $\mathrm{O}_{3}[\mathrm{ppb}]$. Results are shown for DEHM domain number 3 . 
factor of 10.6 is used to convert between the cases of YOLL and the number of premature deaths. Using this factor, the anthropogenic Danish emissions cause approximately 4600 premature deaths in Europe and approximately 800 premature deaths within Denmark. A similar table showing the number of cases related to all European emissions is given in Brandt et al. (2013).

\subsection{The total health-related cost externalities from the major emission sectors and their contributions}

In this section, the external costs are given for the different scenarios, and we present our answers to the main question defined in the Introduction.

Table 4 shows the total health-related external costs in euros for the whole of Europe from Danish emissions, broken down by chemical compound for all the different scenarios. Exposure-response functions are included for both $\mathrm{SO}_{2}$ and $\mathrm{SO}_{4}^{2-}$. However, the emission of sulfur takes place only as $\mathrm{SO}_{2}$, which in the atmosphere is chemically transformed into $\mathrm{SO}_{4}^{2-}$. Therefore the total external costs related to the emission of $\mathrm{SO}_{2}$ should include the human health impacts from both $\mathrm{SO}_{2}$ and $\mathrm{SO}_{4}^{2-}$, and therefore the sum is provided in Table 4 as "Total S". Similarly, the external costs related to $\mathrm{O}_{3}$ and $\mathrm{NO}_{3}^{-}$are summed into "Total N". This cost should be seen in relation to the emission of $\mathrm{NO}_{\mathrm{x}}$, which is a precursor to both $\mathrm{O}_{3}$ and $\mathrm{NO}_{3}^{-}$. As mentioned previously, emissions of $\mathrm{NO}_{\mathrm{x}}$ can lead to both a decrease and an increase of $\mathrm{O}_{3}$ in different areas, and both the costs and the benefits are included in the external costs for $\mathrm{O}_{3}$. The primary emitted parts of $\mathrm{PM}_{2.5}$ (consisting of mineral dust, black carbon, and organic carbon) are treated as inert tracers in the DEHM model, and can therefore be considered as a direct effect due to emissions of the same chemical compound. In Table 4, also the sum of the individual scenarios is given (sum DK/110) together with the results obtained when running all the emissions simultaneously (DK/all). The difference between these numbers is due to the non-linear atmospheric chemistry, where the difference is less than $1 \%$ for the species that can be considered linear ( $\mathrm{CO}$ and $\left.\mathrm{PM}_{2.5}\right)$, while the difference is around $15 \%$ for "Total $\mathrm{S}$ " and "Total N", where the non-linear chemistry is important.

In Table 5, the total health-related externalities for Europe and Denmark are shown for all scenarios EU/1-EU/10, including the 10 major individual emission SNAP categories for Europe and their contribution in \% to the total external cost. Based on the latter, it is possible to assess which emission sectors are most important with respect to impacts on human health. The dominating contributors to health related external costs are as follows: (1) the major power plants (SNAP category 1 ), which contribute $24 \%$ and $17 \%$ of the external health costs in Europe and Denmark, respectively, (2) the agricultural sector with around $25 \%$ (this sector will be discussed later in this section), and (3) the road transport sector, which contributes $18 \%$ and $23 \%$ for Europe and Den- mark, respectively. Following these sectors are non-industrial combustion plants (SNAP 2), in northern Europe dominated by domestic heating and wood burning with around $10 \%$. Combustion in manufacturing industry (SNAP 3), other mobile sources (SNAP 8) and production processes (SNAP 4), contribute 5-7\%. The remaining sectors (SNAP 5, 6 and 9) only contribute a few per cent.

The total external costs due to anthropogenic emissions in Europe, taken as a sum over the ten individual scenarios, are 766 bn (billion) euros in Europe and 3.7 bn euros in Denmark. The corresponding numbers taking into account all emissions (both anthropogenic and natural) in the Northern Hemisphere are 803 bn euros for Europe and 4.5 bn euros for Denmark (Brandt et al., 2013). The difference in these numbers lies both in the difference in the emission areas (Europe or Northern Hemisphere) and in the inclusion of the natural emissions in the latter simulation assessing the impacts from the total air pollution levels as well as on the difference in taking the sum over the ten emission sectors (assuming linearity) or running all sectors simultaneously (assuming nonlinearity).

The total health-related external costs in Europe from all Danish emissions (DK/all) are estimated to be 4.9 bn eu$\mathrm{ros}^{-1} \mathrm{yr}^{-1}$ (sum of DK/all in Table 4), while the same emissions account for an external cost of 817 million euros/year in Denmark alone (not shown in the tables). Since the total external cost in Denmark due to all emissions is 4.5 bn euros, as mentioned above, this suggest that Denmark is a net exporter of health-related external costs in the simulated year.

When comparing the external costs with the sum of the results from all the 10 SNAP categories individually (DK/sum 1-10), a difference appears. The figures to be compared for the sum are 5.68 bn euros $\mathrm{yr}^{-1}$ (sum of "Sum DK/1-10 in Table 4) and 971 million euros/year giving a difference of approximately $15 \%$ (impact in Europe) and 19\% (impacts in Denmark) towards higher costs when the sum of individual assessments is considered. This difference is to be expected and is a consequence of the non-linear atmospheric chemistry. When non-linear processes are involved, the sum of individual processes will in general not equal the results from all the processes together. In the present study, the size of the difference depends very much on the atmospheric chemical regime in the region of interest. The chemical regime depends again on the general air pollution levels in the region. A much larger difference than the $15 \%$ estimate in the Danish region could be expected in other and more highly polluted areas of Europe. Furthermore, the non-linearity will also depend on the size of the emission sources examined; for example, similar investigations for Germany would most likely result in larger non-linear effects. An early study of the non-linear effects of emission reductions is given in BastrupBirk et al. (1997), showing very large differences of the nonlinear effect within Europe.

In Table 6, the relative contributions from all the major Danish emission sectors are given as the percentage of 
Table 5. Total health-related external costs for Europe (billion euros) and Denmark (million euros) from the 10 major individual emission SNAP categories in Europe (DEHM domain 2) for the emission year 2000 as well as their contributions in $\%$ to the total external cost in Europe and Denmark. respectively. All costs are in 2006 prices.

\begin{tabular}{lcccc}
\hline European emission sector & \multicolumn{2}{c}{ Europe } & \multicolumn{2}{c}{ Denmark } \\
\cline { 2 - 5 } & bn euros & \% of cost in Europe & Mio euros & \% of cost in Denmark \\
\hline EU/1 Combustion in energy and transf. industries & 185 & 24.1 & 698 & 18.6 \\
EU/2 Non-indus. combustion plants/wood & 73 & 9.5 & 362 & 9.7 \\
EU/3 Combustion in manufacturing industry & 60 & 7.9 & 258 & 6.9 \\
EU/4 Production processes & 50 & 6.5 & 193 & 5.2 \\
EU/5 Extr. and distr. of fossil fuels/geoth. energy & 10 & 1.3 & 50 & 1.3 \\
EU/6 Solvents and other product use & 13 & 1.7 & 84 & 2.2 \\
EU/7 Road transport & 138 & 18.0 & 857 & 22.9 \\
EU/8 Other mobile sources and machinery & 50 & 6.5 & 255 & 6.8 \\
EU/9 Waste treatment and disposal & 7.8 & 1.0 & 29 & 0.8 \\
EU/10 Agriculture & 180 & 23.5 & 957 & 25.6 \\
\hline Sum EU/1-10 & 766 & 100.0 & 3740 & 100.0 \\
\hline
\end{tabular}

the sum of external costs due to emissions from Denmark (DK/1-10) for the two emission years 2000 and 2008. The contribution is calculated with respect to all external costs in both in the whole of Europe and within Denmark only. The relative contributions depend on whether results are estimated for impacts in the whole of Europe or for impacts within Denmark alone. This can partly be explained by the typical emission heights related to the different sectors. High altitude sources (e.g. stacks from power plants) will result in relatively low human exposure to air pollution in close vicinity of the stacks. For SNAP category 1 (DK/1), which includes the major power plants, the high stacks ensure the spreading of the air pollution away from the population near the source. Further away from the power plants, the effect of emitting at higher altitudes is less pronounced. The results in Table 6 show that the relative contribution from the major power plants with respect to the external costs in Denmark is about half the relative contribution when taking into account external costs in the whole of Europe.

The opposite is seen for SNAP category 2 (DK/2), including the non-industrial combustion plants. In Denmark, SNAP category 2 corresponds to domestic emissions, including domestic heating dominated by wood burning (around $90 \%$ of the health-related external costs from this sector), which typically have a relatively low emission height. In this case, the relative contribution to the external costs within Denmark is nearly twice the relative contribution from the Danish emissions in the whole of Europe. For road traffic, there is also a significant though smaller difference in the relative contribution to Europe and Denmark, the latter being larger.

From Table 6, it is also seen that the largest contributor to human health impacts and related external costs is SNAP category 10 , which is the agricultural sector, where these emissions contribute approximately $40 \%$ of the total external costs due to Danish emissions. The availability of un- bound $\mathrm{NH}_{3}$ in the atmosphere contributes to the formation of ammonium sulfate and ammonium nitrate, which in turn have a significant impact on human health as secondary particles. The external cost of $\mathrm{NH}_{3}$ emissions in the agricultural sector is associated with the exposure-response functions of the sulfate $\left(\mathrm{SO}_{4}^{2-}\right)$ and nitrate $\left(\mathrm{NO}_{3}^{-}\right)$particles, due to the chemical transformation of $\mathrm{NH}_{3}$ into ammonium bisulfate $\left(\mathrm{NH}_{4} \mathrm{HSO}_{4}\right)$, ammonium sulfate $\left(\left(\mathrm{NH}_{4}\right)_{2} \mathrm{SO}_{4}\right)$ and ammonium nitrate $\left(\mathrm{NH}_{4} \mathrm{NO}_{3}\right)$. The mass of ammonium $\left(\mathrm{NH}_{4}^{+}\right)$ must be included in the total particle mass associated with these particles (ExternE, 1999). According to WHO (2006), it is currently not possible to quantify precisely the contributions of different chemical components of PM, or PM from different sources, to the health effects caused by exposure to PM. Based on the findings of the WHO systematic review project and the recommendations of the Task Force on Health, the effects of PM on mortality are in this study assessed using the total $\mathrm{PM}$ mass $\left(\mathrm{PM}_{2.5}\right)$ as an indicator (WHO, 2006) (see also the discussion in Sect. 2.6). A study carried out for the USA population suggests that a $10 \%$ reduction in livestock ammonia emissions can lead to over 4 billion USD annually in particulate-related health benefits (McCubbin et al., 2002). In a newly published assessment for nitrogen in Europe (Brink et al., 2011; Sutton et al., 2011), the total health-related external cost from emission of ammonia in Europe amounts to between 7 bn and 70 bn euros per year. The ammonia emission from the agricultural sector in Denmark is very high, and it is nearly equal to the sum (in ktonnes) of the emissions from all other sectors of $\mathrm{SO}_{2}, \mathrm{NO}_{\mathrm{x}}$, and $\mathrm{PM}_{2.5}$ for the year 2000. Therefore, it can be expected that the health-related external cost owing to emissions from this sector is large in Denmark. The emissions of $\mathrm{NH}_{3}$ give a large contribution to the external costs for several reasons. (1) The mass of $\mathrm{NH}_{4}^{+}$is included in the dose-response functions for $\mathrm{SO}_{4}^{2-}$ and $\mathrm{NO}_{3}^{-}$as the total particle mass associated 
Table 6. Contributions in \% from Danish anthropogenic emission sectors to the total health-related external costs in Europe and Denmark for two different emission years (2000 and 2008). The numbers in parentheses represent a sensitivity study in order to assess the effects of assigning different toxicity to primary emitted and secondary formed particles with factors of 1.3 and 0.7 respectively according to NEEDS (2007).

\begin{tabular}{lcccc}
\hline Danish emission sector & \multicolumn{2}{c}{ Emission year 2000 } & \multicolumn{2}{c}{ Emission year 2008 } \\
\hline & $\begin{array}{c}\text { \% of cost } \\
\text { in Europe }\end{array}$ & $\begin{array}{c}\text { \% of cost } \\
\text { in Denmark }\end{array}$ & $\begin{array}{c}\text { \% of cost } \\
\text { in Europe }\end{array}$ & $\begin{array}{c}\text { \% of cost } \\
\text { in Denmark }\end{array}$ \\
\hline DK/1 Combustion in energy and transf. industries & 10.3 & 5.7 & 8.5 & $4.4(3.4)$ \\
DK/2 Non-indus. combustion plants/wood & 9.3 & 16.3 & 17.6 & $29.9(39.1)$ \\
DK/3 Combustion in manufacturing industry & 5.3 & 4.3 & 6.7 & $4.3(3.6)$ \\
DK/4 Production processes & 1.9 & 3.1 & 1.8 & $2.4(1.9)$ \\
DK/5 Extr. and dist. fossil fuels/geoth. energy & 1.7 & 2.3 & 1.4 & $1.8(1.4)$ \\
DK/6 Solvents and other product use & 2.6 & 2.5 & 2.0 & $2.0(1.5)$ \\
DK/7 Road transport & 17.6 & 19.3 & 17.4 & $16.3(17.7)$ \\
DK/8 Other mobile sources and machinery & 7.9 & 7.2 & 7.9 & $5.4(5.6)$ \\
DK/9 Waste treatment and disposal & 0.6 & 0.1 & 0.5 & $0.4(0.3)$ \\
DK/10 Agriculture & 42.8 & 39.4 & 36.2 & $33.2(25.5)$ \\
\hline Sum: DK/1-10 & 100.0 & 100.0 & 100.0 & $100.0(100.0)$ \\
\hline
\end{tabular}

with these particles must be included, as explained above. (2) Nitric acid $\left(\mathrm{HNO}_{3}\right)$ is already present in the atmosphere from other sources - this is true for the whole of Europe. When $\mathrm{NH}_{3}$ is emitted, it reacts with $\mathrm{HNO}_{3}$ to form $\mathrm{NH}_{4} \mathrm{NO}_{3}$. $\mathrm{HNO}_{3}$ deposits relatively fast (close to zero surface resistance) compared to $\mathrm{NH}_{4} \mathrm{NO}_{3}$. The lower deposition rate of $\mathrm{NH}_{4} \mathrm{NO}_{3}$ therefore leads to increased atmospheric concentration of $\mathrm{NO}_{3}^{-}$in particulate form in areas with higher $\mathrm{NH}_{3}$ emissions. (3) The $\mathrm{SO}_{4}^{2-}$ concentration is not increased in itself, but the particle mass from $\mathrm{NH}_{4}^{+}$is included in the mass for the $\mathrm{SO}_{4}^{2-}$ exposure-response function.

The results for the base year 2000 in this work show that the major Danish contributors to the total health-related external costs with respect to impacts in the whole of Europe are agriculture with a contribution of $43 \%$, road traffic with a contribution of $18 \%$ and power production with a contribution of $10 \%$. The non-industrial (domestic) combustion plants contribute $9 \%$, and other mobile sources $8 \%$. The other sectors contribute $5 \%$ or less.

If we restrict our examination of the health-related external costs from Danish anthropogenic sources to only consider impacts within Denmark for the base year 2000, the most dominant sectors are still agriculture with a contribution of $39 \%$ and road traffic with a contribution of $19 \%$. The non-industrial (domestic) combustion increases to $16 \%$ compared to the case where impacts in the whole of Europe were considered. The power production sector contributes $6 \%$, showing that this sector causes relatively less human health impacts when only impacts in Denmark are considered.

To investigate and illustrate the development over time, calculations were also made for the emission year 2008 (using year 2000 meteorology) (see Table 6). The results show a significant decrease in two of the main contributors, namely the major power plants and the agricultural sectors. In both sectors considerable actions have been initiated in order to decrease emissions. However, one sector, SNAP category 2, has increased its contribution by nearly a factor of two. This sector is, as already mentioned, dominated by domestic wood burning, and the wood consumption has increased by around $80 \%$ from 2000 to 2008 .

As in the NEEDS report (NEEDS, 2007), we also performed a sensitivity study in order to assess the effects of assigning different toxicity to primary emitted and secondary formed particles, with factors of 1.3 and 0.7 , respectively. These results are given in parentheses in Table 6. Applying this assumption, the emissions from the domestic wood burning sector have become the major source of health-related external costs in Denmark, while the agricultural sector and road traffic are the second and third most important contributors. A similar sensitivity study has been conducted by Griffiths (2011), who examines the contribution of different emission source sectors to the total exposure associated with a variety of individual $\mathrm{PM}_{2.5}$ components in Europe using the CMAQ air quality model. This study includes a sensitivity study of assigning equal toxicity to all particles compared to the case where toxicity is only assigned to the primary emitted particles. The results obtained by Griffiths (2011) clearly demonstrate the that the relative contribution of different sectors to fine particulate exposure varies significantly depending on whether total, secondary or primary components are being considered. 


\section{Discussions and overall conclusions}

In this paper we have presented a new integrated model system, EVA, based on the impact pathway approach and customized for European conditions. The system is capable of calculating the health-related external costs from specific atmospheric emission sources and sectors, which has been demonstrated in the paper. The system represents an attempt to apply state-of-the-art science, models, data, and methodologies in every link of the impact-pathway chain. Furthermore, we have implemented a tagging method, where the problem with signal-to-noise ratio has been reduced in the calculation of the source contributions (the $\delta$-functions). The EVA system was run for different scenarios, assessing the human health impacts and associated external costs from the ten main emission sectors in Europe and Denmark. Since the conclusions in the paper are sensitive to the toxicity of the different kinds of atmospheric particles, the existing knowledge of health impacts from particles has been discussed. From this discussion, we concluded that with our present knowledge we are not able to distinguish between the impacts from different particle types, and therefore the toxicity of the particles is handled equally. However, we also included a sensitivity study applying higher toxicity to primary emitted particles and lower to secondary formed particles.

One of the major conclusions from this work is that the major contributors from European emissions to the total health-related external costs in the whole of Europe (in order of impact) are power production, agriculture, road traffic, non-industrial (domestic) combustion (including wood combustion), combustion in manufacturing industry, other mobile sources, production processes and solvents and other product use. An important assumption here is that the different secondary inorganic aerosols (SIAs) and the primary emitted particles are equally harmful to human health.

The results for the base year 2000 in this work show that the major Danish contributors to the total health-related external costs with respect to impacts in the whole of Europe are (in order of impact) agriculture, road traffic, power production, non-industrial (domestic) combustion plants, other mobile sources, combustion in manufacturing industry and solvents and other product use.

If we restrict our examination of the health-related external costs from Danish anthropogenic sources to consider only impacts within Denmark for the base year 2000, the most dominant sectors are still agriculture and road traffic, but the third most important sector is now non-industrial (domestic) combustion dominated by wood burning. Other mobile sources is also an important contributor.

To investigate and illustrate the development with time, calculations were also made for the emission year 2008. The results showed a significant decrease in two of the main contributors, namely the major power plants and the agricultural sector. However, the non-industrial (domestic) combustion sector increased its contribution by nearly a factor of two.
This sector is dominated by domestic wood burning, which constitutes around $90 \%$ of the external costs from this sector in Denmark, and the wood consumption has increased by around $80 \%$ between these two years. We also performed a sensitivity study in order to assess the effects of assigning higher toxicity to primary emitted and lower toxicity to secondary formed particles, with factors of 1.3 and 0.7 , respectively. Applying this assumption, the emissions from domestic wood burning sector become the major source of healthrelated external costs in Denmark from Danish emissions.

The results in this work suggest that the agricultural sector contributes significantly to health impacts and related external costs. The agricultural sector already contributes significantly to impacts on the environment in terms of eutrophication effects in terrestrial and marine ecosystems. From the results in this study, we conclude that not only the impacts on nature should be taken into account when regulating the emissions of ammonia, but also impacts on human health should be considered.

The results in this study show that air pollution constitutes a serious problem for human health and that the related external costs are considerable. The main objective of this work was to find the primary activities and emission sources in Europe and Denmark that give the largest contribution to human health impacts and related external costs taking into account non-linear atmospheric chemistry. The related external costs found in this work can be used to compare directly the contributions from the different emission sectors, potentially as a basis for decision-making on regulation and emission reduction. This study shows that the major visible and already highly regulated emission sources (e.g. power plants and road traffic) do not always constitute the most significant problems related to human health. Other less obvious sources can have significant impacts on nature and human health. Therefore, it is important to make an overall screening of all emission sectors or emission sources in order to create a scientific basis for sound political decisions. In this work, we illustrate the capability of the EVA system to give useful input for the planning and prioritization of regulation policies and instruments.

The economic valuation in this study only includes some of the known harmful chemical compounds. In these calculations, we did not include compounds such as polycyclic aromatic hydrocarbons, persistent organic pollutants, metals, heavy metals, dioxins, and secondary organic aerosols. However, these compounds commonly share the same sources as the compounds included in this study, and the health effects are likely to be included in our calculations due to their correlations with the included compounds, since the exposure-response functions used correlate the $\mathrm{PM}_{2.5}$ concentrations with the total health impacts. Also, the system does not presently include impacts and external costs in relation to the natural environment or climate. Furthermore, taking into account that we only included health impacts where the ERFs are well-documented and accepted by the WHO 
and EU Commission, and that the economic valuation of the health impacts has been conservative, the overall results in this work can also be considered conservative.

The absolute external costs in this work should be interpreted carefully. The external costs are, of course, associated with uncertainties, which are very difficult to quantify in such a complex model system. The main uncertainties in the integrated model system are associated with the emissions (which have an uncertainty of $\pm 30 \%$ on annual basis) and with the health impacts from the individual chemical compounds associated with air pollution (i.e. the ERFs). With our present knowledge, we are not able to distinguish between the impacts from different particle types, and this constitutes a major shortcoming in our knowledge at the moment. However, there are many studies linking the total mass of $\mathrm{PM}_{2.5}$ with health effects, showing strong and significant correlations. Besides the internal uncertainties in the approach, the results will also be dependent on the meteorological year chosen in the study. We chose the year of 2000 as the base year for meteorology since this year has been used in other studies, and it was therefore more straightforward to carry out a comparison of these results with other similar studies, as done in Brandt et al. (2013).

Compared to other similar systems, our goal has been to apply advanced methodologies, models and data in every link of the impact-pathway chain. This involved implementing a method for the calculation of the contribution from specific sources to the air pollution levels, without assuming linearity in the source-receptor relationships, and using a tagging method to reduce the signal-to-noise ratio. Since all scenarios are calculated with the same methodology and assumptions, the relative uncertainty between the scenario results obtained in this work is relatively smaller than the absolute uncertainty.

The current application on regional background scale is a starting point for further improvements and development of the EVA system. Besides the above-mentioned uncertainties used in the DEHM, the results can be sensitive to spatial resolution in the model system. Presently, the system describes the health impacts down to $16.67 \mathrm{~km}^{2}$. However, this resolution is not optimal for describing the condition in the urban background or even in street canyons. Presently an urban background model is being implemented in the model system which can describe the conditions in the urban background with a $1 \mathrm{~km}^{2}$ resolution. The difference between using a relatively course and a relatively fine resolution will be evaluated in the future.

The model outcome in the form of health impacts and economic valuation depends, of course, very much on the concentration-response functions and economic unit prices chosen. However, as both functions are considered linear in the system, another choice of concentration-response functions and economic valuation will have a linear response in the system, and sensitivity to these functions can be applied afterwards. For example, applying a relative risk of
1.03-1.12 instead of 1.06 presently used would imply similar linear responses in the health impacts and economic valuation of half or double the number of premature deaths and equally for the external costs. Furthermore, the response to assigning different toxicities to primary particles and secondary inorganic particles, as carried out in the paper by factors of 1.3 and 0.7 , respectively, can also be done post calculations as impacts and costs are assigned to the individual species before adding everything up to the total impacts and cost. However, many of these uncertainties would not change the relative contribution from the different emission sectors. The main uncertainty is associated with the equal toxicity assigned to all the particles, and the relative contributions would be very sensitive to these choices of different toxicities for different types of particles (e.g. assigning much less toxicity to SIA and much more to primary particles would decrease the relative contributions of, for example, the agricultural sector and increase the relative contribution of, for example, road traffic and domestic heating). An experiment was conducted assigning different toxicities to the primary and secondary particles in order to test the sensitivity of the results to this assumption. A similar experiment has been conducted in Griffiths (2011), where the sensitivity tested assigning zero toxicity to secondary inorganic aerosols and only assigning toxicity to primary emitted particles. In this study the contribution from, for example, the agricultural sector varys from $3 \%$ (including only primary emitted particles) to $36 \%$ including equal toxicity to all particles, which are in line with the results in this paper.

The results in this work emphasize the importance of defining the right questions in the decision-making process, since most of the atmospheric chemical compounds are linked via non-linear chemical reactions. The results represent the case where all the emissions (of all the different chemical compounds) from the sector of interest are reduced simultaneously. In the case where one would like to examine the external cost for the impacts of sulfur alone (e.g. by reducing the sulfur content in the fuel), the model system should be run with the individual emitted compounds one at the time, for example, the sulfur emissions from traffic alone. This would result in different external costs, especially for the countries surrounded by large sulfur emissions from other sources and where the $\mathrm{NO}_{\mathrm{x}}$ emissions are relatively high compared to the $\mathrm{SO}_{2}$ emissions from the traffic sector, as is the case for the Scandinavian countries.

The atmospheric system is highly non-linear, complex and interdependent. Therefore the results from assessing the impacts from each emission sector depend clearly on the assumption that the other emission sectors are not changed. As an example, consider whether the health impacts of emitting ammonia from the agricultural sector would be much lower if all the other emissions from burning fossil fuels were removed. If there is no sulfur oxide or nitrogen oxide available, the ammonia cannot be transformed into ammonium particles. Another example in this work is the relatively high cost 
of sulfur emissions from, for example, the road traffic in Denmark. This is related to the lifetime of $\mathrm{SO}_{2}$ from the international ship traffic in the Baltic Sea and the North Sea, which is influenced by the emissions of $\mathrm{NO}_{\mathrm{x}}$ from the same sector (e.g. road traffic). The $\mathrm{NO}_{\mathrm{x}}$ emissions increase the concentration of $\mathrm{OH}$ in the area, which enhances the transformation rate of the emitted $\mathrm{SO}_{2}$ from ships to sulfate. In this way, the $\mathrm{NO}_{\mathrm{x}}$ emissions increase the sulfate concentrations, which are accounted for in the "Total S" external costs. The emissions are all linked in the chemical composition of the atmosphere via non-linear chemical processes.

The results in this work show that the integrated EVA model system can be used to answer relevant health-related socio-economic questions and can be used for ranking of environmental stressors by health impact (e.g. see Hänninen et al., 2011). However, the results also emphasize that atmospheric chemistry is highly non-linear and that it is impossible without comprehensive, appropriate and well-tested atmospheric models to foresee the results of specific emission reduction scenarios. The results depend highly on geography, emission sector and on how and by how much the emissions are reduced. Therefore, we recommend that health impacts and related external costs should be calculated for specific emission reduction scenarios, if precise estimates of the outcome of specific regulation initiatives are required.

Acknowledgements. The present study is a part of the research of the Centre for Energy, Environment and Health (CEEH), financed by The Danish Strategic Research Program on Sustainable Energy under contract no. 2104-06-0027. Home page is www.ceeh.dk. Special thanks are due to Steffen Loft, University of Copenhagen, for discussions and comments on the health aspect of particle pollution.

Edited by: S. Galmarini

\section{References}

Abbey, D. E., Ostro, B. E., Petersen, F., Burchette, R. J.: Chronic respiratory symptoms associated with estimated log-term ambient concentrations of fine particulates les than 2.5 micron in aerodynamic diameter $\left(\mathrm{PM}_{2.5}\right)$ and other air pollutants, J. Exp. Anal. Environ. Epidemiol., 5, 137-159, 1995.

Abbey, D. E., Nishino, N., Mcdonnell, W. F., Burchette, R. J., Knutsen, S. F., Lawrence Beeson, W., and Yang, J. X.: Long-term inhalable particles and other air pollutants related to mortality in nonsmokers, Am. J. Respir. Crit. Care Med., 159, 373-382, 1999.

Alberini, A., Hunt, A., and Markandya, A.: Willingness to pay to reduce mortality risks: evidence from a three-country contingent valuation study, Environ. Res. Econom., 33, 251-264, 2006.

Alcamo, J., Shaw, R., and Hordijk, L. (eds.): The RAINS Model of Acidification. Science and Strategies in Europe, Kluwer Academic Publishers, Dordrecht, the Netherlands, 402 pp., 1990.

Amann, M., Bertok, I., Cabala, R., Cofala, J., Heyes, C., Gyarfas, F., Klimont, Z., Schöpp, W., and Wagner, F.: A final set of scenarios for the Clean Air For Europe (CAFE) programme,
June 2005, International Institute for Applied Systems Analysis (IIASA) CAFE Scenario Analysis Report No. 6. http://www. iiasa.ac.at/rains/CAFE_files/CAFE-D3.pdf (last access: 2 March 2013), 2005.

Andersen, M. S., Frohn, L. M., Nielsen, J. S., Nielsen, M., Jensen, J. B., Jensen, S. S., Christensen, J., and Brandt, J.: EVA - a nonlinear, Eulerian approach for assessment of health-cost externalities of air pollution. In Biennial Conference of the International Society for Ecological Economics, New Delhi, India, December 2006.

Andersen, M. S., Frohn, L. M., Brandt, J., Jensen, S. S.: External effects from power production and the treatment of wind energy (and other renewables) in the Danish energy taxation system. In: Critical Issues in Environmental Taxation: International and Comparative Perspectives Volume IV edited by: Deketelaere, K., Milne, J. E., Kreiser, L. A., and Ashiabor, H. Oxford University Press, 319-336, 2007a.

Andersen, Z. J., P. Wahlin, O. Raaschou-Nielsen, T. Scheike and S. Loft: Ambient particle source apportionment and daily hospital admissions among children and elderly in Copenhagen. J. Expos. Sci. Environ. Epidemiol., 17, 625-636, $2007 \mathrm{~b}$.

Andersen, M. S., Frohn, L. M., Nielsen, J. S., Nielsen, M., Jensen, S. S., Christensen, J. H., and Brandt, J.: A Non-linear Eulerian Approach for Assessment of Health-cost Externalities of Air Pollution. Proceedings of the European Association of Environmental and Resource Economists 16th Annual Conference, Gothenburg, Sweden, 25-28 June 2008, 23 pp., 2008.

Andersson, C., Bergström, R., and Johansson, C.: Population exposure and mortality due to regional background PM in Europe Long-term simulations of source region and shipping contributions. Atmos. Environ., 43, 3614-3620, 2009.

Bastrup-Birk, A., Brandt, J., Zlatev, Z., and Uria, I.: Studying cumulative ozone exposures in Europe during a 7-year period, J. Geophys. Res., 102, 23917-23935, October 27, 1997.

Bell, M. L., Ebisu, K., Peng, R. D., Samet, J. M., and Dominici, F.: Hospital Admissions and Chemical Composition of Fine Particle Air Pollution, Am. J. Respir. Crit. Care Med., 179, 1115-1120, 2009.

Bønløkke, J. H., Sigsgaard, T., Brandt, J., Frohn, L. M., Flachs, E. M., Brønnum-Hansen, H., and0 Siggaard-Andersen, M.-L.: CEEH Scientific Report No. 7a - Description of the CEEH health effect model. Centre for Energy, Environment and Health Report Series, 76 pp., ISSN 1904-7495. http://www.ceeh.dk/ CEEH_Reports/Report_7a/CEEH_Report_7a.pdf (last access: 2 July 2013), 2011.

Brandt, J., Mikkelsen, T., Thykier-Nielsen, S., and Zlatev, Z.: Using a combination of two models in tracer simulations, Math. Comput. Model., 23, 99-115, 1996.

Brandt, J., Christensen, J. H., Frohn, L. M., Palmgren, F., Berkowicz, R., and Zlatev, Z.: Operational air pollution forecasts from European to local scale, Atmos. Environ., 35, S91-S98, $2001 \mathrm{a}$.

Brandt, J., Christensen, J. H., Frohn, L. M., and Berkovicz, R.: Operational air pollution forecast from regional scale to urban street scale. Part 1: system description, Phys. Chem. Earth B, 26, 781786, 2001b.

Brandt, J., Christensen, J. H., and Frohn, L. M.: Operational air pollution forecast from regional scale to urban street scale. Part 2: performance evaluation, Phys. Chem. Earth B, 26, 825-830, 2001c. 
Brandt, J., Christensen, J. H., Frohn, L. M., and Berkowicz, R.: Air pollution forecasting from regional to urban street scale - implementation and validation for two cities in Denmark, Phys. Chem. Earth, 28, 335-344, 2003.

Brandt, J., Silver, J. D., Christensen, J. H., Andersen, M. S., Geels, C., Gross, A., Hansen, A. B., Hansen, K. M., Hedegaard, G. B., and Skjøth, C. A.: Assessment of Health-Cost Externalities of Air Pollution at the National Level using the EVA Model System. Proceedings from the International Conference on Energy, Environment and Health - Optimisation of Future Energy Systems 2010, 31 May-2 June 2010, Carlsberg Academy, Valby, in: CEEH Scientific Report No. 9, 109-115, 2010.

Brandt, J., Silver, J. D., Frohn, L. M., Geels, C., Gross, A., Hansen, A. B., Hansen, K. M., Hedegaard, G. B., Skjøth, C. A., Villadsen, H., Zare, A., and Christensen, J. H.: An integrated model study for Europe and North America using the Danish Eulerian Hemispheric Model with focus on intercontinental transport, Atmos. Environ., 53, 156-176, doi:10.1016/j.atmosenv.2012.01.011, 2012.

Brandt, J., Silver, J. D., Christensen, J. H., Andersen, M. S., Bønløkke, J. H., Sigsgaard, T., Geels, C., Gross, A., Hansen, A. B., Hansen, K. M., Hedegaard, G. B., Kaas, E., and Frohn, L. M.: Assessment of past, present and future health-cost externalities of air pollution in Europe and the contribution from international ship traffic using the EVA model system, Atmos. Chem. Phys., 13, 7747-7764, doi:10.5194/acp-13-7747-2013, 2013.

Brink, C., van Grinsven, H., Jacobsen, B. H., Rabl, A., Gren, I.M., Holland, M., Klimont, Z., Hicks, K., Brouwer, R., Willems, J., Termansen, M., Velthof, G., Alkemade, R., van Oorschot, M., and Webb, J.: Costs and benefits of nitrogen in the environment. In: The European Nitrogen Assessment, edited: Sutton, M. A., Howard, C. M., Erismann, J. W., Billen, G., Bleeker, A., Grennfelt, P., van Grinsven, H., and Grizzetti, B., Cambridge University Press, 612 pp., 2011.

Christensen, J. H.: The Danish Eulerian Hemispheric Model - a three-dimensional air pollution model used for the Arctic, Atmos. Environ., 31, 4169-4191, 1997.

Christensen, J. H., Brandt, J., Frohn, L. M., and Skov, H.: Modelling of Mercury in the Arctic with the Danish Eulerian Hemispheric Model, Atmos. Chem. Phys., 4, 2251-2257, doi:10.5194/acp-42251-2004, 2004.

Corbett J. J. and Fischbeck, P. S.: Emissions from ships, Science, 278, 823-824, 1997.

DEFRA, 2007: An Economic Analysis to Inform the Air Quality Strategy. Updated Third Report of the Interdepartmental Group on Costs and Benefits. Department of Environment, Food and Rural Affairs in partnership with the Scottish Executive, Welsh Assembly Government and Department of Environment Northern Ireland, 25 pp., 2007.

Dockery, D. W., Arden Pope, C., Xu, X., Spengler, J. D., Ware, J. H., Fay, M. E., Ferris Jr., B. G., and Speizer, F. E.: An association between air pollution and mortality in six U.S. cities, N. Engl. J. Med., 329, 1753-1759, 1993.

Eagan, T. M. L., Bakke, P. S., Eide, G. E., and Gulsvik, A.: Incidence of asthma and respiratory symptoms by sex, age and smoking in a community study, Eur. Respir. J., 19, 599-605, 2002.

Enstrom, J.: Fine particulate air pollution and total mortality among elderly Californians, 1973-2002, Inhal. Toxicol., 17, 803-816, 2005.
EU 2004: Modelling and assessment of the health impact of particulate matter and ozone. Economic commission for Europe, Executive body for the convention on long-range transboundary air pollution, Working group on effects, twenty-third session, Geneva, 1-3 September 2004.

EU 2008: Directive 2008/50/EC of the European Parliament on ambient air quality and cleaner air for Europe, http: //eur-lex.europa.eu/LexUriServ/LexUriServ.do?uri=CELEX: 32008L0050:EN:NOT (last acces: 2 March 2013), 21 May 2008.

European Commission: Recommended interim values for the value of preventing a fatality. DG Environment Cost Benefit analysis, Bruxelles: http://ec.europa.eu/environment/enveco/ others/pdf/recommended_interim_values.pdf, (last access: 10 July 2012), 2001.

ExternE: National Implementation, Germany, Contract JOS3CT95-0010, Contract JOU2-CT-0264, Final Report prepared by IER, http://www.regie-energie.qc.ca/audiences/3526-04/ MemoiresParticip3526/Memoire_CCVK_75_ExternE_Germany. pdf (last access date: 2 March 2013), November 1997.

ExternE, DGXII (JOULE Programme). Externalities of Energy, External project, Report Number 7, Methodology, updated 1998, edited by: Holland, M. R. Foster. D., www.externe.info (last access: 2 March 2013), 1998.

ExternE: ExternE - Externalities of Energy: Vol. 7 Methodology 1998 update, European Commission, Brussels, www.externe. info (last access: 2 March 2013), 1999.

ExternE, : Externalities of Energy Methodology 2005 update, European Commission, Directorate-General for Research Sustainable Energy Systems. Brussels, www.externe.info (last access: 2 March 2013), 2005.

Filleul, L., Rondeau, V., Vandentorren, S., Le Moual, N., Cantagrel, A., Annesi-Maesano, I., Charpin, D., Declercq, C., Neukirch, F., Paris, C., Vervloet, D., Brochard, P., Tessier, J.-F., Kauffmann, F., and Baldi, I.: Twenty five year mortality and air pollution: results from the French PAARC survey, Occup. Environ. Med., 62, 453-460, 2005.

Franklin, M., Zeka, A., and Schwartz, J.: Associations between $\mathrm{PM}_{2.5}$ and all-cause and specific-cause mortality in 27 US communities, J. Expo. Sci. Environ. Epidemiol., 17, 279-287, 2007.

Franklin, M., Koutrakis, P., and Schwartz, P.: The role of particle composition on the association between $\mathrm{PM}_{2.5}$ and mortality, Epidemiology, 19, 680-689, 2008.

Friedrich, R. and Bickel, P.: Environmental External Costs of Transport, Springer, München, 326 pp., 2001.

Frohn, L. M., Christensen, J. H., Brandt, J., and Hertel, O.: Development of a high resolution nested air pollution model for studying air pollution in Denmark, Phys. Chem. Earth, 26, 769-774, 2001.

Frohn, L. M., Christensen, J. H., and Brandt, J.: Development of a high resolution nested air pollution model - the numerical approach, J. Comput. Phys., 179, 68-94, 2002.

Frohn, L. M., Brandt, J., Hertel, O., Christensen, J. H., Geels, C., Andersen, M. S., Nielsen, J. S., Frydendall, J., Hvidberg, M., Jensen, S. S., Petersen, J., and Madsen, P. V.: Assessment of air pollution related damages on human health - and the subsequent costs. Proceedings from the 3rd GLOREAM/ EURASAP Workshop, Modern developments in modelling and chemical data analysis, the Netherlands, September 2005, 8 pp., 2006.

Frohn, L. M., Andersen, M. S., Geels, C., Brandt, J., Christensen, J. H., Hansen, K. M., Nielsen, J. S., Hertel, O., Skjøth, C. A., and 
Madsen, P. V.: EVA - An integrated model system for assessing external costs related to air pollution emissions. A contribution to ACCENT T\&TP, Proceedings from the 2d ACCENT Symposium, 10 pp., 2007.

Geels, C., Christensen, J. H., Frohn, L. M., and Brandt, J.: Simulating spatiotemporal variations of atmospheric $\mathrm{CO}_{2}$ using a nested hemispheric model, Phys. Chem. Earth, Parts A/B/C, 27, 14951505, 2002.

Geels, C., Doney, S., Dargaville, R., Brandt, J., and Christensen, J. H., 2004: Investigating the sources of synoptic variability in atmospheric $\mathrm{CO}_{2}$ measurements over the Northern Hemisphere continents - a regional model study, Tellus, 56B, 35-50, 2004.

Geels, C., Gloor, M., Ciais, P., Bousquet, P., Peylin, P., Vermeulen, A. T., Dargaville, R., Aalto, T., Brandt, J., Christensen, J. H., Frohn, L. M., Haszpra, L., Karstens, U., Rödenbeck, C., Ramonet, M., Carboni, G., and Santaguida, R.: Comparing atmospheric transport models for future regional inversions over Europe - Part 1: mapping the atmospheric $\mathrm{CO}_{2}$ signals, Atmos. Chem. Phys., 7, 3461-3479, doi:10.5194/acp-7-3461-2007, 2007.

Graedel, T. F., Bates, T. S., Bouman, A. F., Cunnold, D., Dignon, J., Fung, I., Jacob, D. J., Lamb, B. K., Logan, J. A., Marland, G., Middleton, P., Pacyna, J. M., Placet, M., and Veldt, C.: A compilation of inventories of emissions to the atmosphere, Global Biogeochem. Cy., 7, 1-26, 1993.

Grell, G. A., Dudhia, J., and Stauffer, D. R.: A description of the fifth-generation Penn State/ NCAR mesoscale model (MM5). NCAR Technical Note NCAR/TN-398+STR, National Center for Atmospheric Research, Boulder, Colorado, USA, 1994.

Griffiths, S. J.: Implications of individual particulate matter component toxicity for population exposure, Air Qual Atmos Health, 4, 189-197, doi:10.1007/s11869-010-0077-4, 2011.

Guenther, A., Hewitt, C., Erickson, D., Fall, R., Geron, C., Graedel, T., Harley, P., Klinger, L., Lerdau, M., McKay, W., Pierce, T., Scholes, B., Steinbrecher, R., Tallamraju, R., Taylor, J., and Zimmerman, P.: A global-model of natural volatile organiccompound emissions, J. Geophys. Res.-Atmos., 100, 8873-8892, 1995.

Guenther, A., Karl, T., Harley, P., Wiedinmyer, C., Palmer, P. I., and Geron, C.: Estimates of global terrestrial isoprene emissions using MEGAN (Model of Emissions of Gases and Aerosols from Nature), Atmos. Chem. Phys., 6, 3181-3210, doi:10.5194/acp-63181-2006, 2006.

Hänninen, O., Knol, A. (eds.), Jantunen, M., Kollanus, V., Leino, O., Happonen, E., Lim, T.-A., Conrad, A., Rappolder, M., Carrer, P., Fanetti, A.-C., Kim, R., Prüss-Üstün, A., Buekers, J., Torfs, R., Iavarone, I., Comba, P., Classen, T., Hornberg, C., and Mekel, O.: European perspectives on Environmental Burden of Disease: Estimates for nine stressors in six countries. THL Reports 1/2011, Helsinki, Finland, 86 pp. and 2 appendices. ISBN 978-952-245-413-3, http://en.opasnet.org/w/Ebode (last access: 4 January 2013), 2011.

Hansen, K. M., Christensen, J. H., Brandt, J., Frohn, L. M., and Geels, C.: Modelling atmospheric transport of $\alpha$ hexachlorocyclohexane in the Northern Hemispherewith a 3-D dynamical model: DEHM-POP, Atmos. Chem. Phys., 4, 11251137, doi:10.5194/acp-4-1125-2004, 2004.

Hansen, K. M., Christensen, J. H., Brandt, J., Frohn, L. M., Geels, C., Skjøth, C. A., and Li, Y.-F.: Modeling short-term variabil- ity of alpha-hexachlorocyclohexane in Northern Hemispheric air, J. Geophys. Res., 113, D02310, doi:10.1029/2007JD008492, 2008a.

Hansen, K. M., Halsall, C. J., Christensen, J. H., Brandt, J., Geels, C., Frohn, L. M., and Ambelas Skjøth, C.: The role of the snowpack on the fate of alpha-HCH in an atmospheric chemistrytransport model, Environ. Sci. Technol., 42, 2943-2948, 2008 b.

Hedegaard, G. B., Brandt, J., Christensen, J. H., Frohn, L. M., Geels, C., Hansen, K. M., and Stendel, M.: Impacts of climate change on air pollution levels in the Northern Hemisphere with special focus on Europe and the Arctic, Atmos. Chem. Phys., 8, 3337-3367, doi:10.5194/acp-8-3337-2008, 2008.

Hedegaard, G. B., Christensen, J. H., Geels, C., Gross, A., Hansen K. M., May, W., Zare, A., and Brandt, J.: Modelling the Impacts of Climate Change on Tropospheric Ozone over three Centuries, Atmos. Clim. Sci., 2, 546-561, doi:10.4236/acs.2012.24050, 2012.

Hedegaard, G. B., Christensen, J. H., and Brandt, J.: The relative importance of impacts from climate change vs. emissions change on air pollution levels in the 21st century, Atmos. Chem. Phys., 13, 3569-3585, doi:10.5194/acp-13-3569-2013, 2013.

Heyes, C., Schöpp, W., Amann, M., and Unger, S.: A Simplified Model to Predict Long-Term Ozone Concentrations in Europe. Working paper, WP-96-12. IIASA, Laxenburg, Austria, 1996.

Holland, M., Hunt, A., Hurley, F., Navrud, S., and Watkiss, P.: Methodology for the Cost-Benefit Analysis for CAFE: Volume 1: Overview of Methodology, Didcot, UK, AEA Technology Environment, 2005.

Hurley, F., Hunt, A., Cowie, H., Holland, Miller, B., Pye, S., and Watkiss, P.: Development of Methodology for the CBA of the Clean Air For Europe (CAFE) Programme, Volume 2: Health Impact Assessment, Report for European Commission DG Environment, 2005.

Jerrett, M., Burnett, R. T., Ma, R., Arden Pope, C., Krewski, D., Newbold, K. B., Thurston, G., Shi, Y., Finkelstein, N., Calle, E. E., and Thun, M. J.: Spatial analysis of air pollution and mortality in Los Angeles, Epidemiology, 16, 727-736, 2005.

Jones-Lee, M., Hammerton, M., and Philips, P.: The value of safety: results of a national sample survey, Econ. J., 95, 49-72, 1985.

Katsouyanni, K., Touloumi, G., Spix, C., Schwartz, J., Balducci, F., Medina, S., Rossi, G., Wojtyniak, B., Sunyer, J., Bacharova, L., Schouten, J. P., Ponka, A., and Anderson, H. R.: Short-term effects of ambient sulphur dioxide and particulate matter on mortality in 12 European cities: results from time series data from the APHEA project. Air Pollution and Health: a European Approach, British Med. J., 314, 1658-1663, 1997.

Klaassen, G., Amann, M., Berglund, C., Cofala, J., HöglundIsaksson, L., Heyes, C., Mechler, R., Tohka, A., Schöpp, W., and Winiwarter, W.: The extension of the RAINS model to greenhouse gases. Technical Report IR-04-015, International Institute for Applied Systems Analysis, Laxenburg, Austria, 2004.

Krewitt, W., Mayerhofer, P., Trukenmüller, A., and Friedrich, R.: Application of the impact pathway analysis in the context of LCA, Int. J. Life Cycle Assess., 3, 86-94, 1998.

Krewski D., Burnett, R. T., Goldberg, M. S., Hoover, K., Siemiatycki, J., Abrahamowicz, M., and White, W. H.: Re-analysis of the Harvard Six-cities study and the American Cancer Society Study of air pollution and mortality, Cambridge, MA, USA, Health Effects Institute, 2000. 
Krewski, D., Jerrett, M., Burnett, R. T., Ma, R., Hughes, E., Shi, Y., Turner, M. C., Arden Pope III, C., Thurston, G., Calle, E. E., and Thun, M. J.: Extended Follow-Up and Spatial Analysis of the American Cancer Society Study Linking Particulate Air Pollution and Mortality, Health Effects Insitute Research Report, 140, 1-154, 2009.

Krupnick, A., Ostro, B., and Bull, K.: Peer review of the methodology of cost-benefit analysis of the clean air for Europe programme http://www.cafe-cba.org/ reports-on-developing-the-cba-framework/ (last access: 2 March 2011), 2005.

Laden, F., J. Schwartz, F. E. Speizer and D. W. Dockery, 2006: Reduction in fine particulate air pollution and mortality: Extended follow-up of the Harvard Six Cities study, Am. J. Resp. Crit. Care Med., 173, 667-672, 2006.

Lim, S. S., Vos, T., Flaxman, A. D., Danaei, G., Shibuya, K., AdairRohani, H., Amann, M, Anderson, H. R., Andrews, K. G., Aryee, M., Atkinson, C., Bacchus, L. J., Bahalim, A. N., Balakrishnan, K., Balmes, J., Barker-Collo, S., Baxter, A., Bell, M. L., Blore, J. D., Blyth, F., Bonner, C., Borges, G., Bourne, R., Boussinesq, M., Brauer, M., Brooks, P., Bruce, N. G., Brunekreef, B., BryanHancock, C., Bucello, C., Buchbinder, R., Bull, F., Burnett, R. T., Byers, T. E., Calabria, B., Carapetis, J., Carnahan, E., Chafe, Z., Charlson, F., Chen, H., Chen, J. S., Cheng, A. T.-A., Child, J. C., Cohen, A., Colson, K. E., Cowie, B. C., Darby, S., Darling, S., Davis, A., Degenhardt, L., Dentener, F., Des Jarlais, D. C., Devries, K., Dherani, M., Ding, E. L., Dorsey, E. R., Driscoll, T., Edmond, K., Ali, S. E., Engell, R. E., Erwin, P. J., Fahimi, S., Falder, G., Farzadfar, F., Ferrari, A., Finucane, M. M., Flaxman, S., Fowkes, F. G. R., Freedman, G., Freeman, M. K., Gakidou, E., Ghosh, S., Giovannucci, E., Gmel, G., Graham, K., Grainger, R., Grant, B., Gunnell, D., Gutierrez, H. R., Hall, W., Hoek, H. W., Hogan, A., Hosgood III, H. D., Hoy, D., Hu, H., Hubbell, B. J., Hutchings, S. J., Ibeanusi, S. E., Jacklyn, G. L., Jasrasaria, R., Jonas, J. B., Kan, H., Kanis, J. A., Kassebaum, N., Kawakami, N., Khang, Y.-H., Khatibzadeh, S., Khoo, J.-P., Kok, C., Laden, F., Lalloo, R., Lan, Q., Lathlean, T., Leasher, J. L., Leigh, J., Li, Y., Lin, J. K., Lipshultz, S. E., London, S., Lozano, R., Lu, Y., Mak, J., Malekzadeh, R., Mallinger, L., Marcenes, W., March, L., Marks, R., Martin, R., McGale, P., McGrath, J., Mehta, S., Mensah, G. A., Merriman, T. R., Micha, R., Michaud, C., Mishra, V., Hanafiah, K. M., Mokdad, A. A., Morawska, L., Mozaffarian, D., Murphy, T., Naghavi, M., Neal, B., Nelson, P. K., Nolla, J. M., Norman, R., Olives, C., Omer, S. B., Orchard, J., Osborne, R., Ostro, B., Page, A., Pandey, K. D., Parry, C. D. H., Passmore, E., Patra, J., Pearce, N., Pelizzari, P. M., Petzold, M., Phillips, M. R., Pope, D., Pope III, C. A., Powles, J., Rao, M., Razavi, H., Rehfuess, E. A., Rehm, J. T., Ritz, B., Rivara, F. P., Roberts, T., Robinson, C., Rodriguez-Portales, J. A., Romieu, I., Room, R., Rosenfeld, L. C., Roy, A., Rushton, L., Salomon, J. A., Sampson, U., Sanchez-Riera, L., Sanman, E., Sapkota, A., Seedat, S., Shi, P., Shield, K., Shivakoti, R., Singh, G. M., Sleet, D. A., Smith, E., Smith, K. R., Stapelberg, N. J. C., Steenland, K., Stöckl, H., Stovner, L. J., Straif, K., Straney, L., Thurston, G. D., Tran, J. H., Van Dingenen, R., Van Donkelaar, A., Veerman, J. L., Vijayakumar, L., Weintraub, R., Weissman, M. M., White, R. A., Whiteford, H., Wiersma, S. T., Wilkinson, J. D., Williams, H. C., Williams, W., Wilson, N., Woolf, A. D., Yip, P., Zielinski, J. M., Lopez, A. D., Murray, C. J. L., and Ezzati, M.: A compara- tive risk assessment of burden of disease and injury attributable to 67 risk factors and risk factor clusters in 21 regions, 19902010: a systematic analysis for the Global Burden of Disease Study 2010, The Lancet, 380, 2224-2260. doi:10.1016/S01406736(12)61766-8, 2012.

Liu, S., Krewski, D., Shi, Y., Chen, Y., and Burnett, R. T.: Association between maternal exposure to ambient air pollutants during pregnancy and fetal growth restriction, J. Expo Sci. Environ. Epidemiol. 17, 426-432, 2007.

Logan, J. A.: An analysis of ozonesonde data for the troposphere: Recommendations for testing 3-D models, and development of a gridded climatology for tropospheric ozone, J. Geophys. Res., 104, 115-116, 149, 1999.

Mareckova, K., Wankmueller, R., Anderl, M., Muik, B., Poupa, S., and Wieser, M.: Inventory review 2008: Emission data reported under the LRTAP convention and NEC directive. status of gridded data. Technical report, EMEP Centre on Emission Inventories and Projections, www.ceip.at/fileadmin/inhalte/emep/pdf/ Inventory_Review_2008.pdf (last access: 2 March 2013), 2008.

Maynard, D., Coull, B. A., Gryparis, A., and Schwartz, J.: Mortality risk associated with short-term exposure to traffic particles and sulfates, Environ. Health Perspect., 115, 751-755, 2007.

McCubbin, D. R., Apelberg, B. J., Roe, S., and Divita, F.: Livestock Ammonia Management and Particulate-Related Health Benefits, Environ. Sci. Technol., 36, 1141-1146, 2002.

NEEDS: Deliverable 3.7 - RS1b/WP3 "A set of concentrationresponse functions" 167 pp., NEEDS, New Energy Externalities Developments for Sustainability, http://www.needs-project.org/ RS1b/NEEDS_Rs1b_D3.7.pdf (last access: 2 March 2013), 2007.

Nielsen, J. S., Chilton, S., Jones-Lee, M., Metcalf, H.: How would you like your gain in life expectancy to be provided? An experimental approach, J. Risk Uncert., 41, 195-218, 2010.

OECD: Cost-benefit analysis and the environment: recent developments, Paris. ISBN 92-64-01004-1 - Copyright: OECD 2006, 27 pp., http://www.oecd.org/dataoecd/37/53/36190261.pdf (last access date: 2 March 2013), 2006.

Olesen, H. R., Winther, M., Ellermann, T., Christensen, J., and Plejdrup, M.: Ship emissions and air pollution in Denmark: Present situation and future scenarios, Environmental Project 1306, Danish Environmental Protection Agency, 2009.

Olivier, J. G. J. and Berdowski, J. J. M.: Global emissions sources and sinks. In J. Berdowski, R. Guicherit, and B. J. Heij, editors, The Climate System, 33-78, A. A. Balkema Publishers/Swets \& Zeitlinger Publishers, Lisse, The Netherlands, 2001.

Ostro, B., Feng, W. Y., Broadwin, R., Green, S., and Lipsett, M.: The effects of components of fine particulate air pollution on mortality in California: results from CALFINE, Environ. Health Perspect., 115, 13-19, 2007.

Ostro, B., Lipsett, M., Reynolds, P., Goldberg, D., Hertz, A., Garcia, C., Henderson, K. D., and Bernstein, L.: Long-Term Exposure to Constituents of Fine Particulate Air Pollution and Mortality: Results from the California Teachers Study. Environ. Health Perspect., 118, 363-369, 2010.

Pearson, J. F., C. Bachireddy, S. Shyamprasad, A. B. Goldfine, and J. S. Brownstein: Association between fine particulate matter and diabetes prevalence in the U.S., Diabetes Care, 33, 2196-2201, 2010.

Pelucchi, C., Negri, E., Gallus, S., Boffetta, P., Tramacere, I., and Vecchia, C. L.: Long-term particulate matter exposure and mor- 
tality: a review of European epidemiological studies, BMC Public Health, 9, 453, doi:10.1186/1471-2458-9-453, 2009.

Peng, R. D., Bell, M. L., Geyh, A. S., McDermott, A., Zeger, S. L., Samet, J. M., and Dominici, F.: Emergency admissions for cardiovascular and respiratory diseases and the chemical composition of fine particle air pollution, Environ. Health Perspect., 117, 957-963, 2009.

Pfister, G. G., Emmons, L. K., Hess, P. G., Lamarque, J.-F., Orlando, J. J., Walters, S., Guenther, A., Palmer, P. I., and Lawrence, P. J.: Contribution of isoprene to chemical budgets: A model tracer study with the NCAR CTM MOZART-4, J. Geophys. Res., 113, D05308, doi:10.1029/2007JD008948, 2008.

Pizzol, M., Thomsen, M., Frohn, L., and Andersen, M. S.: External costs of atmospheric $\mathrm{Pb}$ emissions: valuation of neutrotoxic impacts due to inhalation, Environ. Health, 9, 1-9, 2010.

Pope III, C. A., Thun, M. J., Namboodiri, M. M., Dockery, D. W., Evans, J. S., Speizer, F. E., Heath Jr., C. W.: Particulate air pollution as a predictor of mortality in a prospective study of U.S. adults, Am. J. Respir. Crit. Care Med., 151, 669-674, 1995.

Pope, C. A.: Particulate matter-mortality exposure-response relations and threshold, Am. J. Epidemiol., 152, 407-412, 2000.

Pope, C. A., Burnett, R. T., Thun, M. J., Calle, E. E., Krewski, D., Ito, K., and Thurston, G. D.: Lung cancer, cardiopulmonary mortality and longterm exposure to fine particulate air pollution, J. Am Med. Assoc., 287, 1132-1141, 2002.

Pope, C. A., Ezzati, M., and Dockery, D. W.: Fine-particulate air pollution and life expectancy in the United States, New England J. Med., 360, 376-386, 2009.

Raaschou-Nielsen, O., Palmgren, F., Jensen, S. S., Wåhlin, P., Berkowicz, R., Hertel, O., Vrang, M.-L., and Loft, S. H.: Helbredseffekter af partikulær luftforurening i Danmark - et fors $\varnothing \mathrm{g}$ på kvantificering, Ugeskrift for Læger, 164, 3959-3963, 2002.

Rohr, A. C. and Wyzga, R. E.: Attributing health effects to individual particulate matter constituents, Atmos. Environ., 62, 130$152,2012$.

Schlesinger, R. B., Kunzli, N., Hidy, G. M., Gotschi, T., and Jerrett, M.: The health relevance of ambient particulate matter characteristics: Coherence of toxicological and epidemiological inferences, Inhal. Toxicol., 18, 95-125, 2006.

Schultz, M. G., Heil, A., Hoelzemann, J. J., Spessa, A., Thonicke, K., Goldammer, J.,, Held, and Pereira, J. M.: Global emissions from wildland fires from 1960 to 2000, Global Biogeochem. Cy., 22, GB2002, doi:10.1029/2007GB003031, April 2008, 2008.

Schwartz, J., Alexeeff, S. E., Mordukhovich, I., Gryparis, A., Vokonas, P., Suh, H., and Coull, B. A.: Association between long-term exposure to traffic particles and blood pressure in the Veterans Administration Normative Aging Study, Occup. Environ. Med., 69, 422-427 doi:10.1136/oemed-2011-100268, 2012.

Šikoparija, B., Smith, M., Skjøth, C. Ambelas., Radišić, P., Milkovska, S., Šimić, S., and Brandt, J.: The Pannonian Plain as a source of Ambrosia pollen in the Balkans, Int. J. Biometeorol., 53, 263-272, doi:10.1007/s00484-009-0212-9, 2009.

Solazzo, E., Bianconi, R., Vautard, R., Wyat Appel, K., Moran, M. D., Hogrefe, C., Bessagnet, B., Brandt, J., Christensen, J. H., Chemel, C., Coll, I., Denier van der Gon, H., Ferreira, J., Forkel, R., Francis, X. V., Grell, G., Grossi, P., Hansen, A. B., Jericevi, A., Kraljevi, L., Miranda, A. I., Nopmongcol, U., G. Pirovano, M. Prank, A. Riccio, K. N. Sartelet, M. Schaap, J. D. Silver, R. S. Sokhi, J. Vira, J. Werhahn, R. Wolkem, G. Yarwood, J. Zhang,
S. Trivikrama Rao, S. Galmarini, 2012a: Model evaluation and ensemble modelling of surface-level ozone in Europe and North America in the context of AQMEII, Atmos. Environ., 53, June 2012, 60-74, doi:10.1016/j.atmosenv.2012.01.003, 2012a.

Solazzo, E., Bianconi, R., Pirovano, G., Matthias, V., Vautard, R., Appel, K. W., Bessagnet, B., Brandt, J., Christensen, J. H., Chemel, C., Coll, I., Ferreira, J., Forkel, R., Francis, X. V., Grell, G., Grossi, P., Hansen, A., Miranda, A. I., Moran, M. D., Nopmongco, U., Parnk, M., Sartelet, K. N., Schaap, M., D. Silver, J., Sokhi, R. S., Vira, J., Werhahn, J., Wolke, R., Yarwood, G., Zhang, J., Rao, S. T., Galmarin, S.: Operational model evaluation for particulate matter in Europe and North America in the context of the AQMEII project, Atmos. Environ., 53, June 2012, 75-92 doi:10.1016/j.atmosenv.2012.02.045, 2012b.

Solazzo, E., Bianconi, R., Pirovano, G., Moran, M. D., Vautard, R., Hogrefe, C., Appel, K. W., Matthias, V., Grossi, P., Bessagnet, B., Brandt, J., Chemel, C., Christensen, J. H., Forkel, R., Francis, X. V., Hansen, A. B., McKeen, S., Nopmongcol, U., Prank, M., Sartelet, K. N., Segers, A., Silver, J. D., Yarwood, G., Werhahn, J., Zhang, J., Rao, S. T., and Galmarini, S.: Evaluating the capability of regional-scale air quality models to capture the vertical distribution of pollutants, Geosci. Model Dev., 6, 791-818, doi:10.5194/gmd-6-791-2013, 2013.

Sudo, K. and Akimoto, H.: Global source attribution of trophospheric ozone: long-range transport from various source regions, J.Geophys. Res., 112, D12302, doi:10.1029/2006JD007992, 2007.

Sutton, M. A., Howard, C. M., Erisman, J. W., Billen, G., Bleeker, A., Grennfelt, P., van Grinsven, H., Grizzetti, B. (eds): The European Nitrogen Assessment, Cambridge Univ. Press, Cambridge, 664 pp., 2011.

Vautard, R., Schaap, M., van Loon, M., Bergström, R., Bessagnet, B., Brandt, J., Builtjes, P. J. H., Christensen, J. H., Cuvelier, C., Foltescu, V., Graff, A., Jonson, J. E., Kerschbaumer, A., Krol, M., Langner, J., Roberts, P., Rouil, L., Stern, R., Tarrasón, L., Thunis, P., Vignati, E., White, L., and Wind, P.: "Skill and uncertainty of a regional air quality model ensemble, Atmos. Environ., 43, 4822-4832. doi:10.1016/j.atmosenv.2008.09.083, 2009.

Watkiss, P., Pye, S., and Holland, M.: CAFE CBA: Baseline Analysis 2000 to 2020. Service Contract for Carrying out Cost-Benefit Analysis of Air Quality Related Issues, in particular in the clean Air for Europe (CAFE) Programme, April 2005, http://www. cafe-cba.org/assets/baseline_analysis_2000-2020_05-05.pdf (last access: 20 November 2012), 2005.

WHO, 2006: Health risks of particulate matter from long-range transboundary air pollution, Joint WHO/Convention Task Force on the Health Aspects of Air Pollution", European centre for Environment and Health, Bonn Office, pp 113. http://www. euro.who.int/__data/assets/pdf_file/0006/78657/E88189.pdf (last access: 20 November 2012).

Yap, C., Beverland, I. J., Heal, M. R., Cohen, G. R., Robertson, C., Henderson, D. E. J., Ferguson, N. S., Hart, C., L., Morris, G., and Agius, R. M.: Association between long-term exposure to air pollution and specific causes of mortality in Scotland, Occup. Environ. Med., 69, 916-924, doi:10.1136/oemed-2011-100600, 2012.

Zanobetti, A., Franklin, M., Koutrakis, P., and Schwartz, J.: Fine particulate air pollution and its components in association with cause-specific emergency admissions, Environ. Health, 8, 1-12, 
doi:10.1186/1476-069X-8-58, 2009.

Zare, A., Christensen, J. H., Irannejad, P., and Brandt, J.: Evaluation of two isoprene emission models for use in a longrange air pollution model, Atmos. Chem. Phys., 12, 7399-7412, doi:10.5194/acp-12-7399-2012, 2012.
Zare, A., Christensen, J. H., Gross, A., Irannejad, P., Glasius, M., and Brandt, J.: Quantifying the contributions of natural emissions to ozone and total fine PM concentrations in the Northern Hemisphere, Atmos. Chem. Phys. Discuss., 13, 16775-16830, doi:10.5194/acpd-13-16775-2013, 2013. 